\title{
The low-grade basement at Península La Carmela, Chilean Patagonia: new data for unraveling the pre-Permian basin nature of the Eastern Andean Metamorphic Complex
}

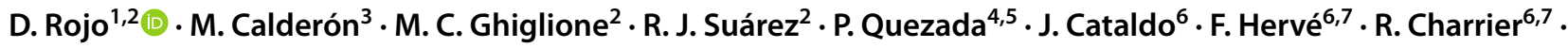 \\ G. Galaz $\cdot$ M. Suárez ${ }^{6} \cdot$ G. Guettner ${ }^{6} \cdot$ M. Babinski ${ }^{9}$
}

Received: 19 October 2020 / Accepted: 20 May 2021

(c) Geologische Vereinigung e.V. (GV) 2021

\begin{abstract}
The Eastern Andean Metamorphic Complex at Península La Carmela (48 $50^{\circ}$ 'S) consists of quartz-rich metaturbiditic sequences with tectonic slices of pillow metabasalt bodies deformed under low-grade metamorphic conditions. Previous and new detrital zircon $\mathrm{U}-\mathrm{Pb}$ geochronological data from metasandstones indicate a preferred early Carboniferous maximum depositional age of the protolith, interpreted from the youngest single zircon grains of several metasedimentary rocks in the area. The wide spectrum of zircon ages from Península La Carmela, includes Neoproterozoic-early Paleozoic components and subordinate ancient zircon grains (>2200 Ma). They were sourced from cratonic regions and/or reworked material from older metasedimentary successions and plutonic belts in southwestern Gondwana (e.g., North Patagonian and Deseado massifs or from the Tierra del Fuego Igneous and Metamorphic Complex). The pillow metabasalts have geochemical affinities of normal mid-oceanic ridge basalts and island-arc tholeiites with $\mathrm{Nb}$-Ta negative anomalies, derived from a depleted mantle source $\left(\varepsilon \mathrm{Nd}_{\mathrm{t}}\right.$ of +6 and +7.5$)$. In consideration that pillow metabasalts with ocean island basalt affinities are reported, we propose that metaturbiditic successions and metabasalts were tectonically juxtaposed within a pre-Permian accretionary wedge of an active continental margin, after the development of island arcs and back-arc marginal basins.
\end{abstract}

Keywords Eastern Andean Metamorphic Complex · Southwestern Gondwana · Pillow metabasalts · Back-arc basalts Metaturbiditic sequences · Accretionary wedge

D. Rojo

d.rojomartel@gmail.com

1 Facultad de Ingeniería Y Arquitectura, Universidad Arturo Prat, Av. Arturo Prat 2120, Iquique, Chile

2 Instituto de Estudios Andinos IDEAN (Universidad de Buenos Aires - CONICET), Buenos Aires, Argentina

3 Facultad de Ingeniería, Universidad del Desarrollo, Av. Plaza 680, Las Condes, Chile

4 Departamento de Ciencias Naturales Y Tecnología, Universidad de Aysén, Obispo Vielmo 62, Coyhaique, Chile

5 Instituto LAMIR, Universidade Federal Do Paraná, Centro Politécnico, Jardim das Américas, Curitiba, PR 81531-980, Brazil
6 Carrera de Geología, Facultad de Ingeniería, Universidad Andrés Bello, Sazié, 2129 Santiago, Chile

7 Departamento de Geología, Universidad de Chile, Plaza Ercilla 803, Santiago, Chile

8 Departamento de Geología, Universidad de Atacama, Copayapu 485, Copiapó, Chile

9 Mineralogy and Geotectonic Department, Geosciences Institute, University of São Paulo, São Paulo, Brazil 


\section{Introduction}

The tectonic evolution of metamorphic complexes in southern Patagonia has been broadly related to the Gondwanide orogeny (Thomson and Hervé 2002; Giacosa et al. 2012; Suárez et al. 2021). The late Paleozoic Gondwanide orogeny (after Du Toit 1927) has been associated to the collision of the continental block of Patagonia (Fig. 1A) against southwestern margin of Gondwana (Ramos 2008). An alternative scenario, proposed by Pankhurst et al. (2006), considers the mid-Carboniferous collision of Deseado Massif continental block against to southern portion of the North Patagonian Massif (Fig. 1A).

Metamorphic rocks in the continental basement of southern Patagonian Andes $\left(48^{\circ} \mathrm{S}\right.$ to $\left.52^{\circ} \mathrm{S}\right)$ correspond mainly to metasedimentary and metavolcanic units grouped into the Eastern Andean Metamorphic Complex (EAMC). The EAMC include Upper Devonian-lower Carboniferous and Permian-Lower Triassic low-grade and polydeformed metaturbiditic sequences (Hervé et al. 2003; Augustsson and Bahlburg 2003; Augustosson et al. 2006)
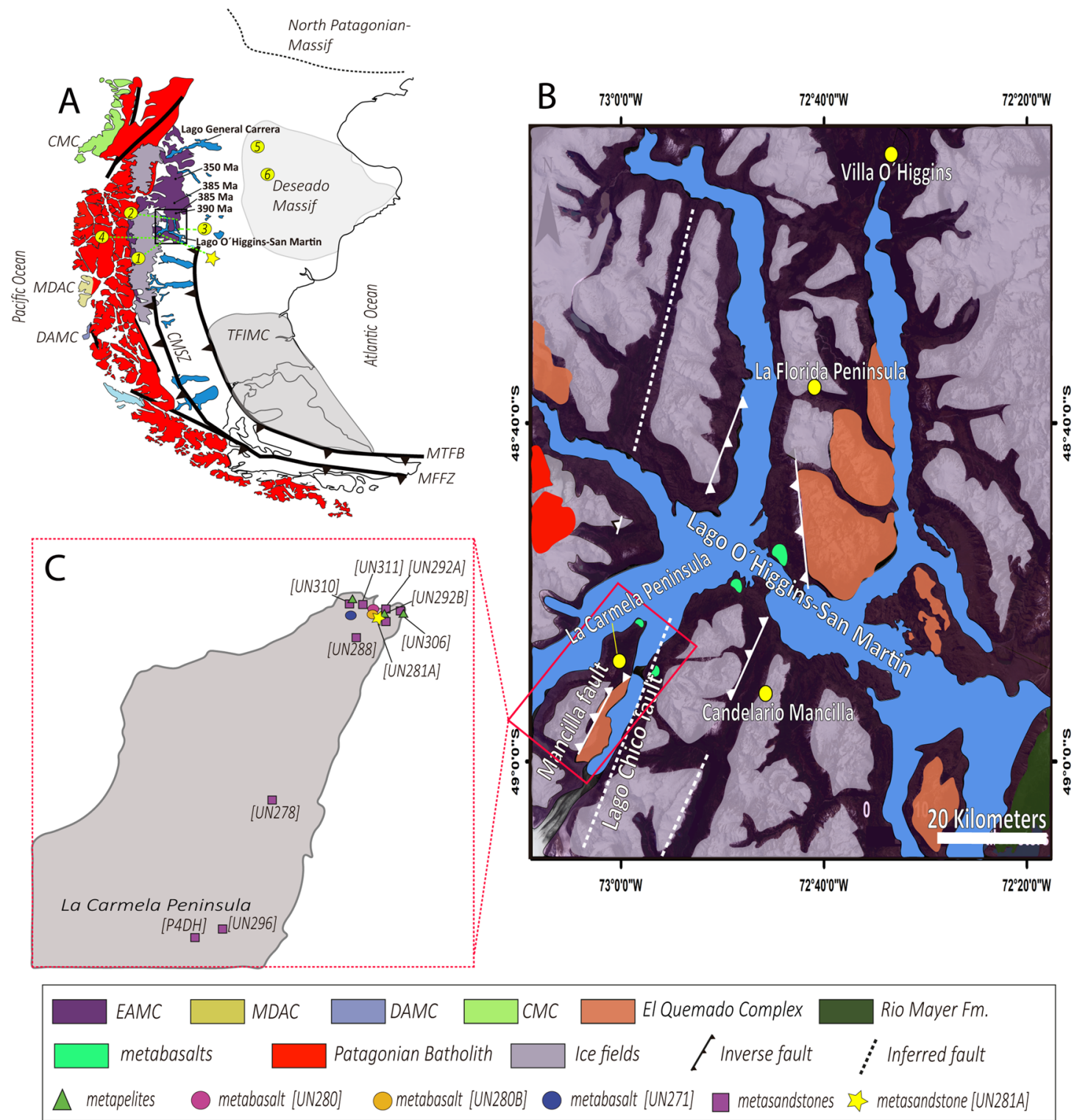

Fig. 1 A Sketch map of different metamorphic complexes of Patagonian modified from Calderón et al. (2016); B local geological sketch of the Lago O`Higgins-San Martín. Modified to De la Cruz and Suárez (2004) and Rojo (2017); C La Carmela Peninsula with a spot of samples analyzed. TFIMC: Tierra del Fuego Metamorphic Complex;
DYC: Duque de York Complex; NV: Nunatak Unit; CMC: Chonos Metamorphic Complex; MDAC: Madre de Dios Accretionary Complex; SASZ: Seno Arcabuz Shear Zone; CMSZ; Canal de las Montañas; MTFB: Magallanes Thrust and Fold Belt; MFFZ: MagallanesFagnano Fault Zone 
and isolated bodies of pillow metabasalts, greenschists, serpentinites and marbles of unknown age (Hervé et al. 1995, 1999, 2008: Quiroz and Belmar 2010; Rojo et al. 2018, 2021). The geodynamic setting for the sedimentary protolith of the EAMC has been a matter of long-lasting debate. Some authors argued that the sediments were deposited in a passive margin (Augustsson and Bahlburg 2003, 2008; Lacassie 2003; Augustsson et al. 2006), while others suggested an active margin setting with or without development of a magmatic arc (Hervé et al. 2003; Calderón et al. 2016; Suárez et al. 2021). Several authors have proposed the existence of an active margin with east-dipping subduction, which is registered by SilurianDevonian magmatic arc roots in the extra-Andean Deseado Massif (Guido et al. 2004, 2005; Pankhurst et al. 2006; Ramos 2008; Ramos and Naipauer 2014). The youngest metasedimentary units of the EAMC were deposited during the Permian and Triassic times and sourced from a magmatic arc and continental basement rocks (Augustsson and Bahlburg 2008). In this context, the late Paleozoic to early Triassic reorganization of crustal blocks of the south-western margin of Gondwana would have caused the westward migration of the magmatic arc because of the accretion/collision of the Antarctic Peninsula against the Gondwana margin (Calderón et al. 2016; Suárez et al. 2019a, b; Rojo et al. 2021). The Permian-Lower Triassic igneous rocks and orthogneisses in Antarctic Peninsula (Graham Land and Marie Byrd Land; Millar et al. 2002; Bastías et al. 2020) are the potential sedimentary sources that fed the depocenter of basins represented by the Trinity Peninsula Group in Antarctic Peninsula (cf. Castillo et al. 2016) and probably the Duque de York Complex (cf. Forsythe and Mpodozis 1979) and younger units of the EAMC in southwestern Patagonia (cf. Hervé et al. 2003; Augustsson et al. 2006; Suárez et al. 2019a,b).

We focus on the geochemical composition of metabasalts from EAMC to obtain primary information for unravelling the tectonic setting of magmatism, considering that basaltic magmas correspond to melts directly extracted from the mantle without or with little crustal assimilation (e.g.,Pearce and Cann 1973; Shervais 1982; Cabanis and Lecolle 1989; Saunders and Tarney 1984; Pearce 2008, 2014; Saccani 2015; Xia and Li 2019). Studies focused on the geochemical and isotopic features of mafic and ultramafic bodies in the EAMC are scarce, but necessary to interpret the basin configuration and tectonic evolution of the south-western margin of Gondwana. Thus, this work aims to characterize the low-grade metamorphic rocks belonging to the EAMC exposed at Península La Carmela on the western shore of the Lago O'Higgins-San Martín (Fig. 1B, C). The integration of new and previous data on detrital zircon $\mathrm{U}-\mathrm{Pb}$ geochronology of metasedimentary rocks and the diverse geochemical composition of metabasalts allow the discussion of the challenging origin and tectono-metamorphic evolution of the EAMC.

\section{Geological background}

The low-grade metamorphic rocks of the EAMC $\left(46-52^{\circ} \mathrm{S}\right)$ are covered in angular unconformity by Upper Jurassic volcanic rocks (Lagally 1975; Giacosa et al. 2012; Suárez et al. 2021) and intruded by the Meso-Cenozoic Patagonian Batholith (Pankhurst et al. 1999; Hervé et al. 2007). Highgrade metamorphic rocks and migmatites are reported along the eastern margin of the South Patagonian batholith (Calderón et al. 2007).

The EAMC is constituted mainly by polydeformed metaturbiditic successions with scarce tectonic slices of pillow metabasalts, serpentinites and marbles (Quiroz and Belmar 2010; Hervé et al. 2008; Rojo et al. 2021). The metasedimentary rocks were initially referred to as Cochrane and Lago General Carrera formations (Lagally 1975), around the Cochrane locality $\left(47^{\circ} 20^{\prime} \mathrm{S}\right)$ and Lago General Carrera (46 $30^{\circ}$ 'S), respectively (Fig. 1A). Older units of the EAMC have been correlated with the Upper Devonian-lower Carboniferous Bahía de la Lancha and Río Lácteo formations in Argentina (47 $30^{\prime}$ S and $49^{\circ} \mathrm{S}$ Riccardi 1971; Giacosa and Márquez 2002). They are partially contemporaneous with the deposition of the sedimentary protolith of the Cerro Negro Schists (Permuy-Vidal et al. 2014) located farther east, near the northwestern area of the Deseado Massif (Fig. 1A).

Based on petrographic and $\mathrm{U}-\mathrm{Pb}$ detrital zircon data, Augustsson et al. (2006) indicated that Upper Devonianlower Carboniferous metasedimentary sequences were sourced from Ordovician, Devonian, and early Carboniferous felsic continental sources. The Permian-early Triassic metasedimentary rocks of the EAMC are mostly located to the west of the South Patagonian Ice Field (Fig. 1A) and were fed by an active continental magmatic arc and country rocks (Augustsson et al. 2006; Augustsson and Bahlburg 2008).

In northern areas of the EAMC $\left(46-47^{\circ} \mathrm{S}\right)$, Ramírez et al. (2005) estimated P-T conditions of metamorphism at 3-5 kbar and $320-380{ }^{\circ} \mathrm{C}$, recording a moderately highgeothermal gradient which is similar to those reported in orogenic and accretionary environments. Hervé et al. (1999) calculated lower $\mathrm{P}-\mathrm{T}$ gradients around $360{ }^{\circ} \mathrm{C}$ and $2-4 \mathrm{Kbar}$ based in the low-grade metamorphic mineral assemblages in basaltic pillow lavas from Península La Florida (Fig. 1B). Thus, although the pressure values are lower than those of 
a typical accretionary prism (e.g., Chonos Metamorphic Complex; Willner et al. 2000), the P-T conditions exhibited by the EAMC are in the range expected for regional metamorphism during back-arc basin closure (e.g., Muller et al. 2021) rather than for subduction zone complexes (RamírezSánchez et al. 2005; Willner et al. 2009). Zircon fissiontrack thermochronology records a late Permian cooling age which is related to the last stages of regional metamorphism (Thomson and Hervé 2002). A late Mesozoic thermal overprint, linked to the batholith emplacement, is revealed by ${ }^{40} \mathrm{Ar} /{ }^{39} \mathrm{Ar}$ white mica ages in metapelites (Ramírez-Sánchez et al. 2007). At these latitudes, the geochemical compositions of metabasalt bodies distributed into the EAMC $\left(44^{\circ}\right.$ to $52^{\circ} \mathrm{S}$ ), show chemical affinities with island-arc tholeiites (IAT), back-arc basin basalts (BABB) and normal midoceanic ridge basalts (N-MORB) (Godoy 1979; Quiroz and Belmar 2010; Rojo et al. 2021).

Particularly, the metamorphic rocks at Lago O’HigginsSan Martín (48-49 ${ }^{\circ}$; Fig. 1B) consist mainly of quartz-rich metasedimentary rocks with tectonic slices of metabasalts and metacherts. Outcrops of metabasalts are well exposed at La Carmela and La Florida peninsulas. Metasandstones in this area show marked detrital zircon populations of Ordovician, Cambrian and Mesoproterozoic ages, with one isolated grain of ca. $355 \mathrm{Ma}$ (Hervé et al. 2003). Farther south, Malkowsky et al. (2016) reported a similar age pattern but with three grains of Devonian age and one isolated grain of ca. 320 Ma. Metabasalts at Peninsula La Florida shows geochemical affinities akin to ocean island basalts (OIB) in which $\mathrm{P}-\mathrm{T}$ constraints of $2-4 \mathrm{kbar}$ and $360{ }^{\circ} \mathrm{C}$ have been estimated (Hervé et al. 1999). Low-grade metabasalts at Península La Carmela preserve pillow structures and are described petrographically and geochemically in this work.

\section{Methods}

\section{Petrography}

The petrographic study of mineral assemblages, textures and microstructures was performed in 40 thin sections of representative rocks from Península La Carmela (Fig. 1C). The metasedimentary rocks show subtle recrystallization and were classified based on their matrix content and modal compositions following Pettijohn et al. (1973). Metamafic rocks were classified based on their relict mineralogy and textures.

\section{$\mathrm{U}-\mathrm{Pb}$ detrital zircon geochronology}

The sensitive high-resolution ion microprobe (SHRIMP) $\mathrm{U}-\mathrm{Pb}$ ages for detrital zircons were determined from one sample of metasandstone (sample UN281-A), from which 71 zircon grains were randomly selected (Table 1). The analytical work was carried out at the Research School of Earth Sciences, the Australian National University, Canberra, using SHRIMP RG followed cathodoluminescence (CL) imaging of the zircon grains. We consider an analysis concordant when there is an overlap of ${ }^{206} \mathrm{~Pb} /{ }^{238} \mathrm{U},{ }^{207} \mathrm{~Pb} /{ }^{235} \mathrm{U}$, and ${ }^{207} \mathrm{~Pb} /{ }^{206} \mathrm{~Pb}$ ages and plotted on the U-Pb Tera-Wasserburg diagram and crystallization ages with uncertainties given at one $\sigma$ level. Frequency histogram and probability density distribution for detrital zircons ages were constructed using Isoplot 3.0 software (Ludwig 2003). The plot is built from the preferred concordant ages for single grains $(n=65)$. The preferred age considers the ${ }^{206} \mathrm{~Pb} /{ }^{238} \mathrm{U}$ ratios if the detrital zircons are younger than $1.2 \mathrm{Ga}$, whereas the ${ }^{207} \mathrm{~Pb} /{ }^{206} \mathrm{~Pb}$ ratios are used if the detrital zircon grains are older than $1.2 \mathrm{Ga}$.

\section{Geochemistry and isotopic analyses}

The major and trace element composition of metabasalts (Table 2) were obtained by inductively coupled plasma mass-spectrometry (ICP-MS) at Activation Analytical Laboratories in Vancouver, Canada. Two samples of metabasalts were selected for $\mathrm{Sr}$ and $\mathrm{Nd}$ isotope analyses carried out at the Centro de Pesquisas Geocronológicas, Instituto de Geociências, Universidade de São Paulo (USP, Brazil). The Sr and $\mathrm{Nd}$ isotope determinations were carried out at CPGeo at Universidade de São Paulo, Brazil, and were analysed using the Thermal Ionization Mass Spectrometry (TIMS) Thermo Triton. The Sr isotopic ratios were normalized to ${ }^{86} \mathrm{Sr} /{ }^{88} \mathrm{Sr}=0.1194$ and replicate analyses of ${ }^{87} \mathrm{Sr} /{ }^{86} \mathrm{Sr}$ for the NBS987 standard gave a mean value of $0.71028 \pm 0.00006$ $(2 \sigma)$. The $\mathrm{Nd}$ isotopic compositions were normalized to ${ }^{143} \mathrm{Nd} /{ }^{144} \mathrm{Nd}=0.72190$. The averages of ${ }^{143} \mathrm{Nd} /{ }^{144} \mathrm{Nd}$ for $\mathrm{La}$ Jolla and BCR-1 standards were $0.511847 \pm 0.00005(2 \sigma)$ and $0.512662 \pm 0.00005$, respectively (Table 3 ). The calculation of initial isotopic ratios $(t=347 \mathrm{Ma})$ considered the elemental composition ( $\mathrm{Rb}, \mathrm{Sr}, \mathrm{Sm}, \mathrm{Nd})$ determined by ICP-MS analyses.

\section{Results}

\section{Petrography and field data}

Metasedimentary and metamafic rocks are the two main lithological units at Península La Carmela, in sharp contact oriented $\sim \mathrm{N} 20 \mathrm{E} / 60 \mathrm{~W}$, nearly parallel to the main foliation (Fig. 2A, B). The metasedimentary rocks consist of metapelites, metasandstones, and metagreywackes showing a penetrative foliation (locally subparallel to $\mathrm{S}_{0}$; Fig. 2C). This is well defined in metapelites with a slaty cleavage $\left(\mathrm{S}_{1}\right)$ subparallel to bedding structures $\left(\mathrm{S}_{0}\right)$, both striking NNE-SSW 


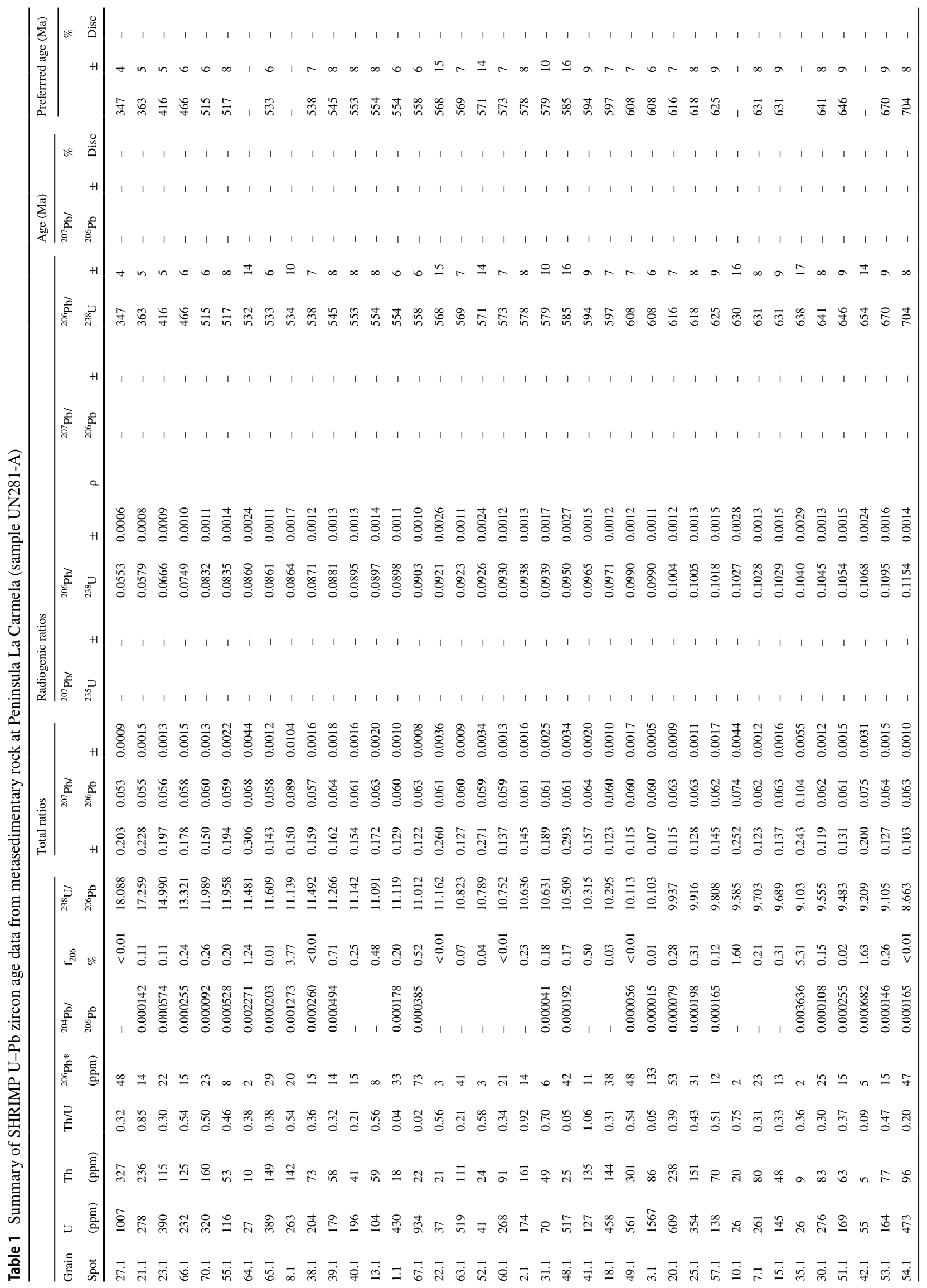




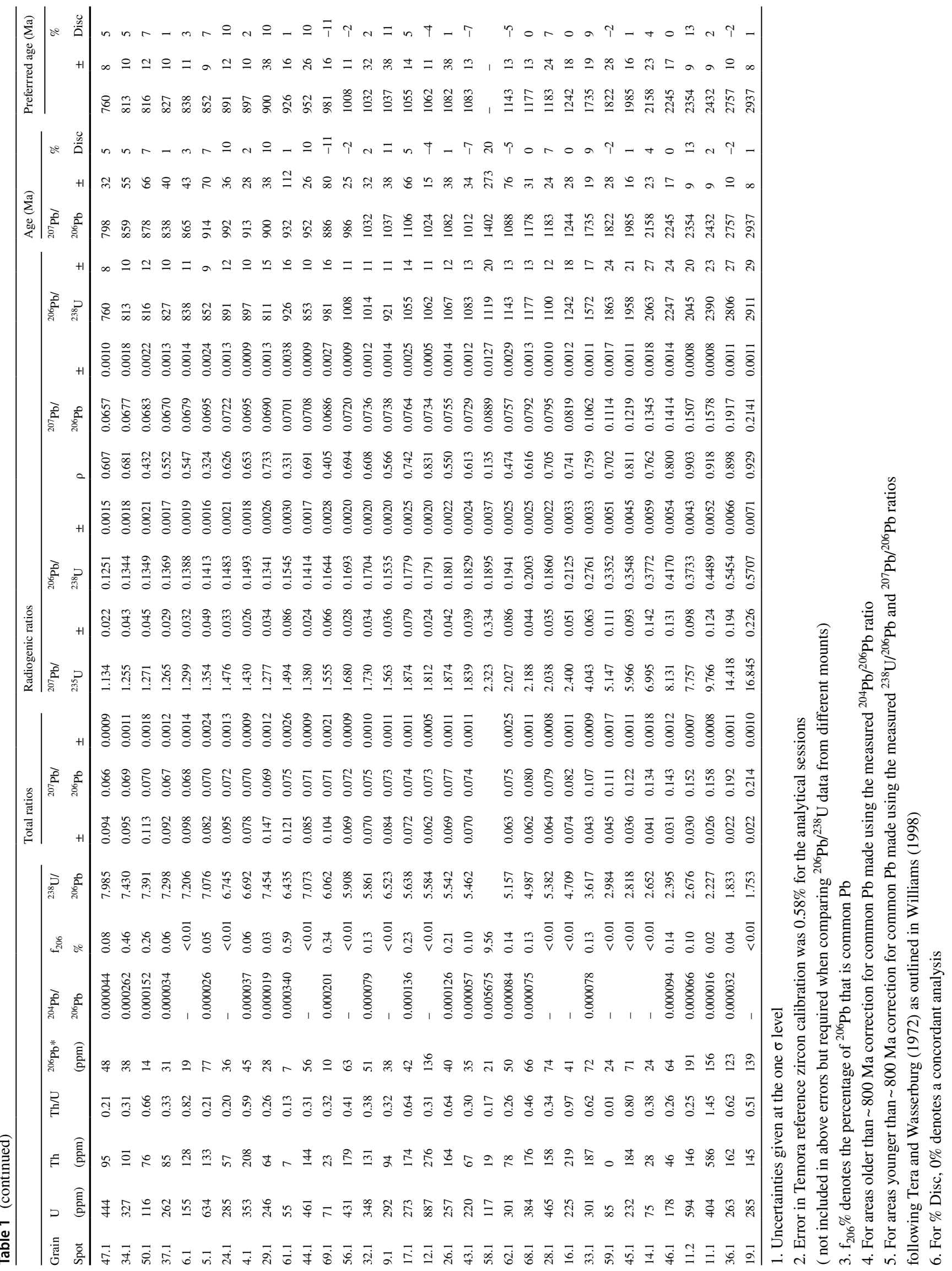


Table 2 Bulk rock chemical compositions of pillow metabasalts from Peninsula La Carmela

\begin{tabular}{|c|c|c|c|c|}
\hline \multirow{2}{*}{$\begin{array}{l}\text { Sample } \\
\text { Rock tipe }\end{array}$} & \multirow[t]{2}{*}{ Detection limit } & \multicolumn{3}{|l|}{ La Carmela } \\
\hline & & $\begin{array}{l}\mathrm{UN}-271 \\
\text { metabasalt }\end{array}$ & $\begin{array}{l}\text { UN-280 } \\
\text { metabasalt }\end{array}$ & $\begin{array}{l}\text { UN-280B } \\
\text { metabasalt }\end{array}$ \\
\hline $\mathrm{SiO} 2$ & 0.01 & 46.86 & 49.35 & 47.69 \\
\hline $\mathrm{A} 12 \mathrm{O} 3$ & 0.01 & 13.87 & 18.19 & 17.51 \\
\hline $\mathrm{FeO}(\mathrm{T})$ & 0.01 & 12.87 & 7.85 & 6.51 \\
\hline $\mathrm{MnO}$ & 0.001 & 0.238 & 0.191 & 0.18 \\
\hline $\mathrm{MgO}$ & 0.01 & 11.9 & 7.05 & 6.36 \\
\hline $\mathrm{CaO}$ & 0.01 & 5.14 & 3.9 & 6.38 \\
\hline $\mathrm{Na} 2 \mathrm{O}$ & 0.01 & 3.27 & 5.53 & 5.51 \\
\hline $\mathrm{K} 2 \mathrm{O}$ & 0.01 & 0.04 & 0.81 & 0.9 \\
\hline $\mathrm{TiO} 2$ & 0.001 & 1.153 & 0.609 & 0.533 \\
\hline $\mathrm{P} 2 \mathrm{O} 5$ & 0.01 & 0.07 & 0.03 & 0.04 \\
\hline LOI & - & 5.29 & 6.45 & 8.04 \\
\hline Sum & - & 100.70 & 99.96 & 99.65 \\
\hline $\mathrm{Sc}$ & 1 & 35 & 27 & 24 \\
\hline $\mathrm{Be}$ & & $<1$ & $<1$ & $<1$ \\
\hline $\mathrm{V}$ & 5 & 282 & 147 & 111 \\
\hline $\mathrm{Cr}$ & 20 & 220 & 370 & 310 \\
\hline Co & 1 & 51 & 35 & 34 \\
\hline $\mathrm{Ni}$ & 20 & 120 & 110 & 100 \\
\hline $\mathrm{Cu}$ & 10 & 20 & 20 & 20 \\
\hline $\mathrm{Zn}$ & 30 & 60 & 70 & 50 \\
\hline $\mathrm{Ga}$ & 1 & 15 & 12 & 10 \\
\hline $\mathrm{Ge}$ & 0.5 & 1.8 & 1.1 & 0.9 \\
\hline As & - & $<5$ & $<5$ & $<5$ \\
\hline $\mathrm{Rb}$ & 1 & $<1$ & 35 & 34 \\
\hline $\mathrm{Sr}$ & 2 & 114 & 207 & 281 \\
\hline $\mathrm{Y}$ & 0.5 & 32.2 & 14.9 & 13.2 \\
\hline $\mathrm{Zr}$ & 1 & 60 & 30 & 27 \\
\hline $\mathrm{Nb}$ & 0.2 & 3.1 & 1.5 & 1.3 \\
\hline Mo & 2 & $<2$ & $<2$ & $<2$ \\
\hline $\mathrm{Ag}$ & 0.5 & $<0,5$ & $<0,5$ & $<0,5$ \\
\hline In & 0.1 & $<0,1$ & $<0,1$ & $<0,1$ \\
\hline $\mathrm{Sn}$ & 1 & 1 & $<1$ & $<1$ \\
\hline $\mathrm{Sb}$ & & 0.3 & $<0,2$ & $<0,2$ \\
\hline Cs & 0.1 & 0.9 & 4.8 & 5.1 \\
\hline $\mathrm{Ba}$ & 2 & 64 & 295 & 347 \\
\hline $\mathrm{La}$ & 0.05 & 3.56 & 1.33 & 1.37 \\
\hline $\mathrm{Ce}$ & 0.05 & 9.17 & 3.98 & 3.72 \\
\hline $\operatorname{Pr}$ & 0.01 & 1.4 & 0.63 & 0.63 \\
\hline $\mathrm{Nd}$ & 0.05 & 8.36 & 3.56 & 3.46 \\
\hline $\mathrm{Sm}$ & 0.01 & 3.17 & 1.37 & 1.23 \\
\hline $\mathrm{Eu}$ & 0.005 & 1.37 & 0.625 & 0.572 \\
\hline $\mathrm{Gd}$ & 0.01 & 4.09 & 1.93 & 1.75 \\
\hline
\end{tabular}

Table 2 (continued)

\begin{tabular}{lllll}
\hline Sample & \multirow{2}{*}{ Detection limit } & \multicolumn{2}{l}{ La Carmela } \\
\cline { 3 - 5 } & & UN-271 & UN-280 & UN-280B \\
Rock tipe & & 0.85 & 0.38 & 0.34 \\
\hline $\mathrm{Tb}$ & 0.01 & 5.43 & 2.68 & 2.36 \\
$\mathrm{Dy}$ & 0.01 & 1.13 & 0.55 & 0.49 \\
$\mathrm{Ho}$ & 0.01 & 3.53 & 1.59 & 1.45 \\
$\mathrm{Er}$ & 0.01 & 0.514 & 0.248 & 0.237 \\
$\mathrm{Tm}$ & 0.005 & 3.24 & 1.71 & 1.52 \\
$\mathrm{Yb}$ & 0.01 & 0.507 & 0.255 & 0.22 \\
$\mathrm{Lu}$ & 0.002 & 1.8 & 0.8 & 0.8 \\
$\mathrm{Hf}$ & 0.1 & 0.19 & 0.12 & 0.04 \\
$\mathrm{Ta}$ & 0.01 & $<0,5$ & 9.5 & 2.1 \\
$\mathrm{~W}$ & - & $<0,05$ & 0.1 & 0.12 \\
$\mathrm{Tl}$ & - & $<5$ & $<5$ & $<5$ \\
$\mathrm{~Pb}$ & - & $<0,1$ & $<0,1$ & $<0,1$ \\
$\mathrm{Bi}$ & - & 0.27 & 0.14 & 0.17 \\
$\mathrm{Th}$ & 0.05 & 0.17 & 0.79 & 0.72 \\
$\mathrm{U}$ & 0.01 & & & \\
\hline
\end{tabular}

$\left(\sim \mathrm{N} 40^{\circ} \mathrm{E}\right)$ and steeply dipping to the west (Fig. 2). The $\mathrm{S}_{0}-\mathrm{S}_{1}$ foliation is overprinted by a crenulation cleavage $\left(\mathrm{S}_{2}\right)$ with NNW-SSE-strike, and fold axis plunging to the SSE. The metamafic rocks crop out as weakly deformed bodies within metasedimentary rocks, showing discrete foliation planes. These bodies show a green color and exhibit relict pillow structures with diameter of at least $50 \mathrm{~cm}$ (Fig. 2B). Local tensional veins of quartz and carbonate are present. Both lithological units show similar metamorphic grade and orientation of foliation planes.

\section{Metasedimentary rocks}

Metasandstones and metagreywackes are mainly composed by grains of quartz and feldspars with moderate sorting and poor textural maturity (Fig. 3A-C) with a recrystallized matrix proportion varying between 5 and 20\%. Quartz constitutes up to $70 \%$ of the detrital components, exhibiting angular to sub-rounded shapes, undulose extinction and occasionally sutured contacts (Fig. 3A). Feldspars, mostly plagioclase, represent up to $30 \%$ of the detrital grains, which are subrounded and moderately altered to clay minerals. Plagioclase, which is easily recognized by its Carlsbad and polysynthetic twinning, show fractures and intracrystalline dislocations. Lithic fragments $(<3 \%)$ consist of metamorphic rocks (phyllites and quartzites) and subordinate aphanitic 
volcanic and/or subvolcanic rocks (Fig. 3A). Accessory detrital minerals comprise zircon, tourmaline, white mica, biotite and opaques (Fig. 3C). The recrystallized matrix shows a faint foliation defined by discontinuous layers of white mica and chlorite, with traces of microgranular titanite and epidote. The $\mathrm{S}_{0}-\mathrm{S}_{1}$ foliation is defined by compositional layers of micas and cleavage bands (Fig. 3D, E). The folded $S_{1}$ foliation is crosscut by an axial plane cleavage $\left(S_{2}\right.$; Fig. 3F). Metapelites are mainly constituted by preferentially oriented white mica showing a $\mathrm{S}_{2}$ spaced cleavage.

\section{Metabasalts}

The metabasalts have light to dark-green color. The mineralogy of the metamorphosed pillow basalts shows a micro-porphyritic texture defined by euhedral to subhedral phenocrysts of plagioclase with well-defined Carlsbad and polysynthetic twins, and locally a sieve texture, placed in a recrystallized groundmass with microliths of plagioclase (Fig. 3G, H). The primary mineralogy of the metabasalts and its groundmass have been replaced mainly by albite, chlorite, epidote and actinolite (Fig. 3G, H). Late vein of quartz and carbonates are common. The metamorphic mineral assemblage of metabasalts from Península La Carmela is typical of low-grade Greenschist Facies of metamorphism.

\section{Distribution of $\mathrm{U}-\mathrm{Pb}$ ages and maximum depositional age}

The metasedimentary rocks from EAMC are devoid of index fossils and/or interbedded acidic volcanic rocks for performing an absolute dating, thus, the estimation of maximum deposition age considering the $\mathrm{U}-\mathrm{Pb}$ detrital zircon ages have turn out to be a useful tool to constrain the depositional time (Vermeesch 2004; Gehrels et al. 2006; Dickinson and Gehrels 2009; Copeland 2020). Gehrels et al. (2006) and Dickinson and Gehrels (2009) proposed and discussed several methods to estimate the maximum depositional age, such as the youngest single grain, or the mean age of the youngest three or more grains that overlap in age at $2 \sigma$.

In this study, 71 detrital zircons from a metasandstone (sample UN281-A) were dated from which 6 grains with discordant ages were rejected and no further considered in the analysis. The $\mathrm{Th} / \mathrm{U}$ ratios spanning between 0.005 and 1.450 , being $89 \%$ greater than 0.2 , which could indicate an igneous origin for most of the grains. The spectrum of 65 concordant ages ranges from the Meso-Archean to the early Carboniferous (Table 1, Fig. 4A). The ages are distributed into the Archean $(n=2 ; 3 \%)$, Proterozoic $(n=57$, $88 \%)$, and Paleozoic $(n=6 ; 9 \%)$. Age distribution shows several peaks in the probability density plot (Fig. 4A), the most pronounced are Neoproterozoic $(\sim 560 \mathrm{Ma}, \sim 620 \mathrm{Ma}$ 


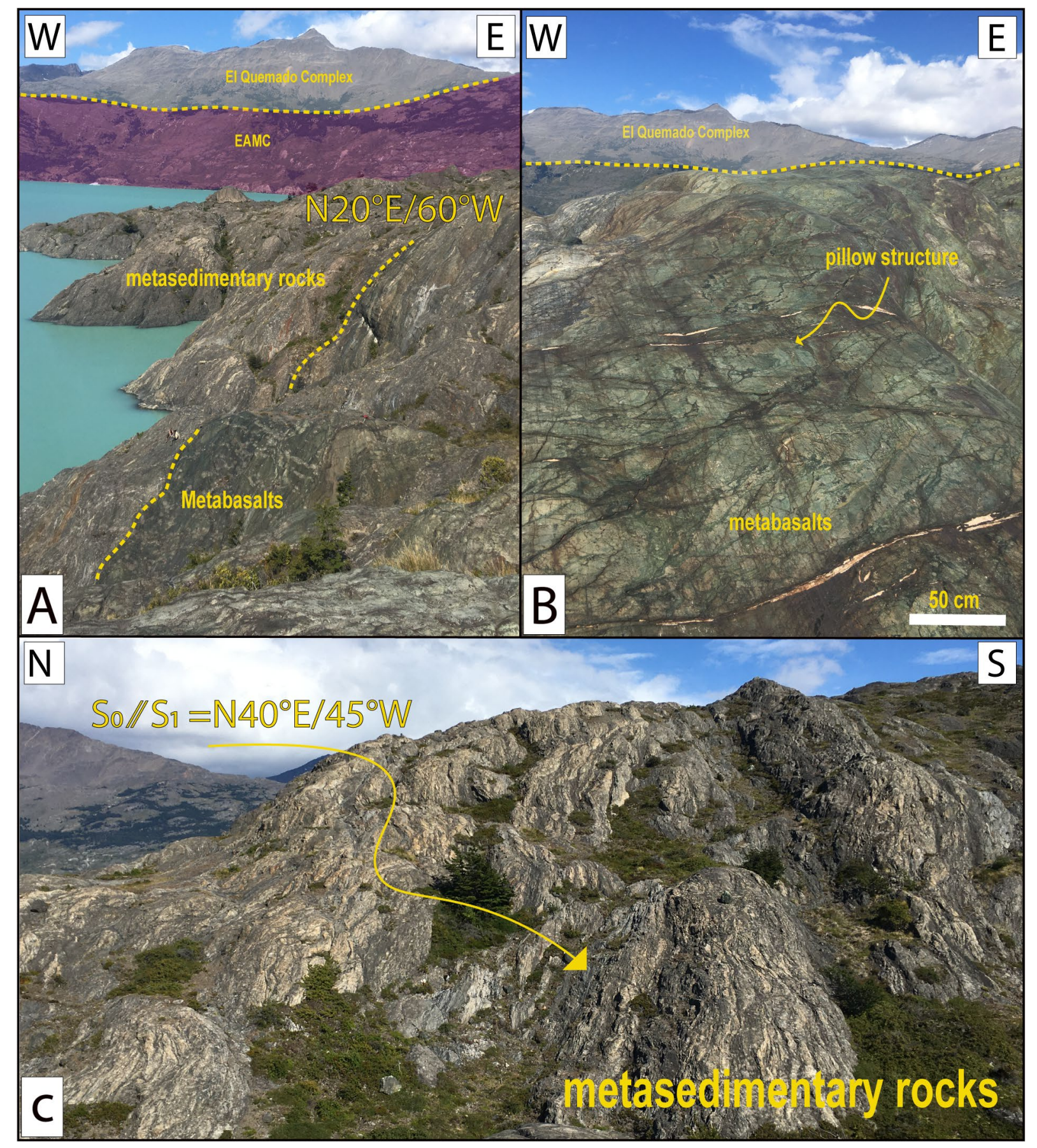

Fig. 2 Field photographs showing $\mathbf{A}$ field relations between the metasedimentary units incontact with metabasic units of the EAMC at Peninsula La Carmela; B metabasic units showing a relict deformed pillow structure; $\mathbf{C}$ metasedimentary unit with two distinctite lithologie (metasandstone and metagreywacka vs. metapelite) 
Fig. 3 A Metamorphic lithic (phyllite) in metasandstone; B angular quartz crystals with mica and clay minerals in matrix, in metasandstone; $\mathbf{C}$ detrital white mica in weakly foliated meta-greywacke; D quartzite lithic in metagreywacke with white mica accommodating the deformation; $\mathbf{E}$ two directions of foliation and recrystallized matrix in metagreywacke; $\mathbf{F}$ inner deformation structure in metagraywacke; $\mathbf{G}$ moderate altered plagioclase of basalts with carbonatic veins (UN-280); $\mathbf{H}$ chlorite development in amygdala of pillow-like metabasalts (UN-280)
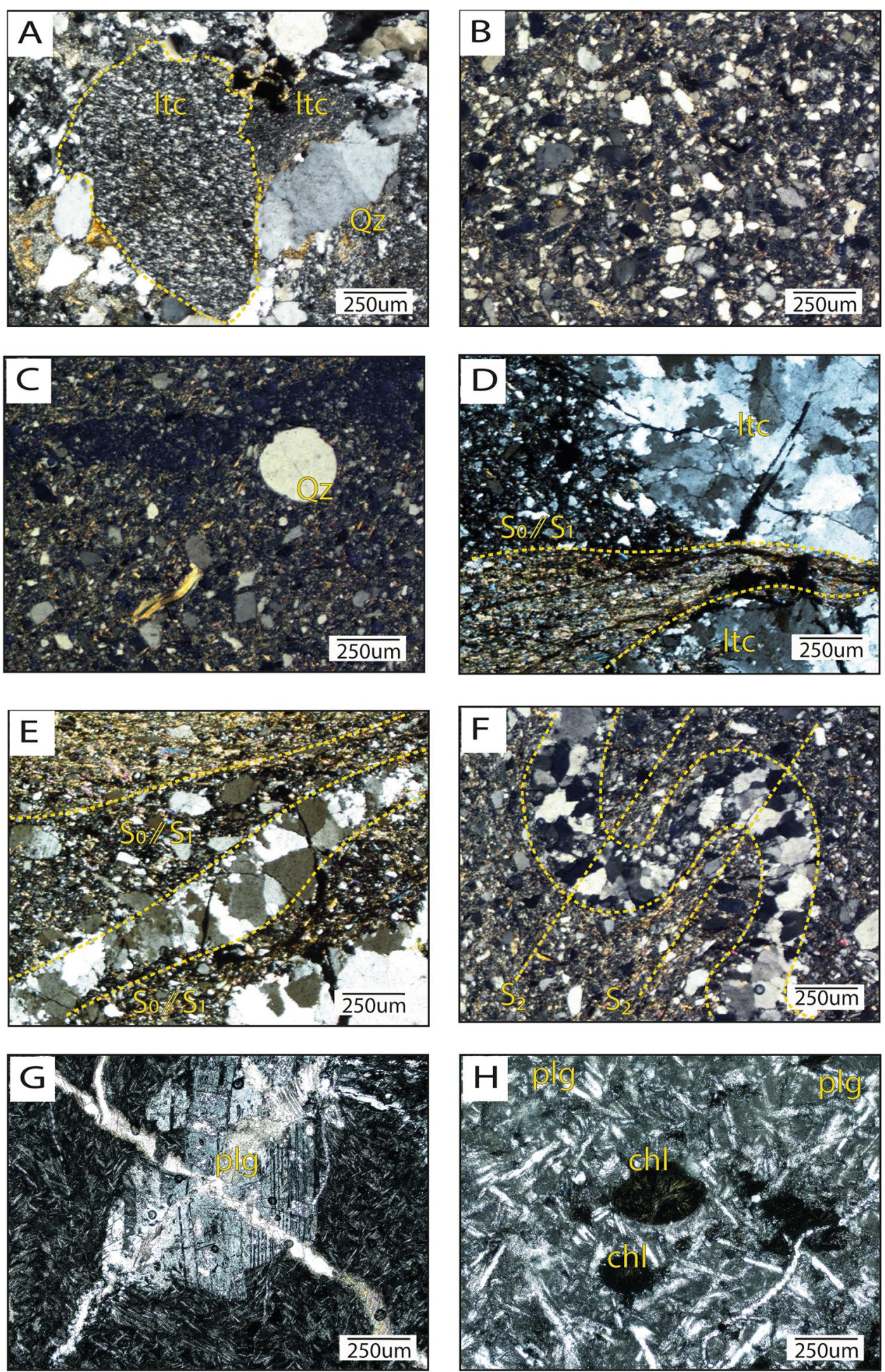
Fig. 4 A, B Probability density plot showing relative probability age of detrital zircon grains from metasandstone (sample UN-281A); C Tera-Wasserburg $\mathrm{U}-\mathrm{Pb}$ Concordia diagrams for SHRIMP analyses from sample UN-281A from Peninsula La Carmela. YSG, indicated the young single grain

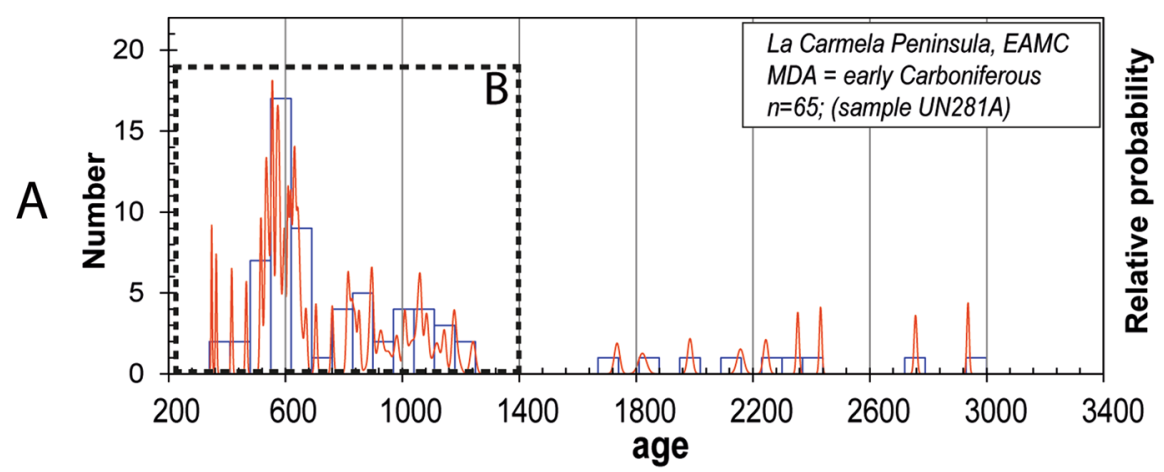

B
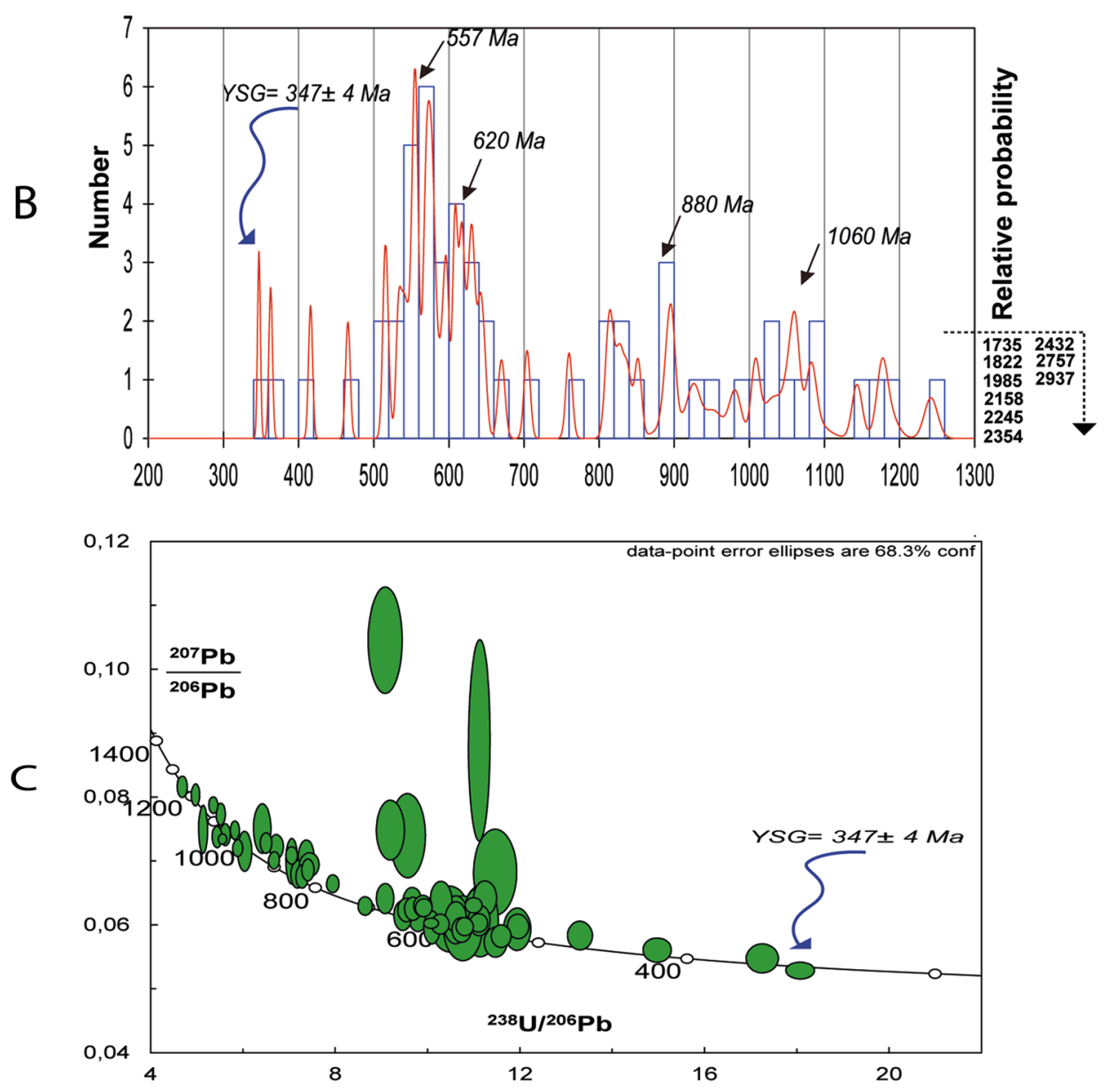
and $\sim 880 \mathrm{Ma}$ ) and Mesoproterozoic ( 1060 Ma) (Fig. 4B). There are only three zircon grains of late Paleozoic age (Fig. 4B). The youngest zircons show a good fitting within the Tera-Wasserburg diagram (Fig. 4C), and that of early Carboniferous age $(347 \pm 4 \mathrm{Ma})$, could be considered as a fairly good maximum depositional age.

\section{Bulk-rock geochemistry and $\mathrm{Sr}-\mathrm{Nd}$ isotopes}

The geochemistry of metabasalts is roughly characterized by low $\mathrm{SiO}_{2}$ content (46.9-49.4 wt\%), moderate to high contents of $\mathrm{MgO}(6.4-11.2 \mathrm{wt} \%)$ and $\mathrm{Al}_{2} \mathrm{O}_{3}(13.9-18.2$ $\mathrm{wt} \%)$, and restricted variations of $\mathrm{TiO}_{2}(0.53-1.15 \mathrm{wt} \%)$, $\mathrm{CaO}$ (3.9-6.4 wt\%). Relatively high LOI values (5.3-8.0 wt\%) reflect the presence of chlorite and carbonates in the rocks (Table 2). The chondrite-normalized Rare Earth Elements (REE) composition of metabasalts define a flat and enriched pattern of REE (Fig. 5A). The samples display $(\mathrm{La} / \mathrm{Sm})_{\mathrm{N}}$ of $0.62-0.72$ and $(\mathrm{La} / \mathrm{Yb})_{\mathrm{N}}$ of $0.55-0.78$ and slightly positive Eu anomaly (Fig. 5A). The multi-element composition normalized to N-MORB (Sun and McDonough 1989), shows that metabasalts are enriched in $\mathrm{Rb}$, $\mathrm{Ba}, \mathrm{U}$, and depleted of $\mathrm{Nb}$ and $\mathrm{Ta}$ suggesting a systematic depletion of high field strength elements (HFSE) relative to large ion lithophile elements (LILE) (Fig. 5B). In general, the metabasic rocks characterized by low to moderate $\mathrm{Mg} \#(\sim 0.5), \mathrm{Ni}(100-120 \mathrm{ppm}), \mathrm{Cr}(220-370 \mathrm{ppm})$, and $\mathrm{Ti}$ (3195 to $6912 \mathrm{ppm}$ ), and low Nb, Ta, Zr, Th, and $\mathrm{U}$ contents (Table 1). The pillow metabasalts plot in the sub-alkaline basalt field based on the $\mathrm{Zr} / \mathrm{TiO}_{2}$ versus $\mathrm{Nb} / \mathrm{Y}$ ratios (Fig. 6A). The samples have low $\mathrm{Zr}$ and $\mathrm{Zr} / \mathrm{Y}$ as well in $\mathrm{Th} / \mathrm{Yb}$ and $\mathrm{Nb} / \mathrm{Yb}$ ratios, suggesting a N-MORB affinity (Fig. 6B, C). The low to moderate V/Ti ratios are consistent with a MORB without discriminate between back-arc basalt (BABB) or fore-arc basalt (FAB) (Fig. 6D). In ternary diagrams, all samples plot in the N-MORB (Fig. 6E, F).

The Sr-Nd isotopic composition of pillow metabasalts show a relatively uniform compositional range (Table 2). Assuming an early Carboniferous age of basalts (ca. $350 \mathrm{Ma})$, the calculated initial ${ }^{87} \mathrm{Sr} /{ }^{86} \mathrm{Sr}$ ratios are elevated, varying between 0.71103 and 0.71111 . The high values could be related post-magmatic chemical modifications driven by seafloor hydrothermal metamorphism. The potential contamination with crustal material during magma ascent cannot be excluded, but probably is negligible and undetectable. The elevated $\varepsilon \mathrm{Nd}(\mathrm{t})$ values ranging between +6.0 and +7.5 (Fig. 7), signal a depleted mantle source for basalts, which ultimately were emplaced under subaquatic conditions.

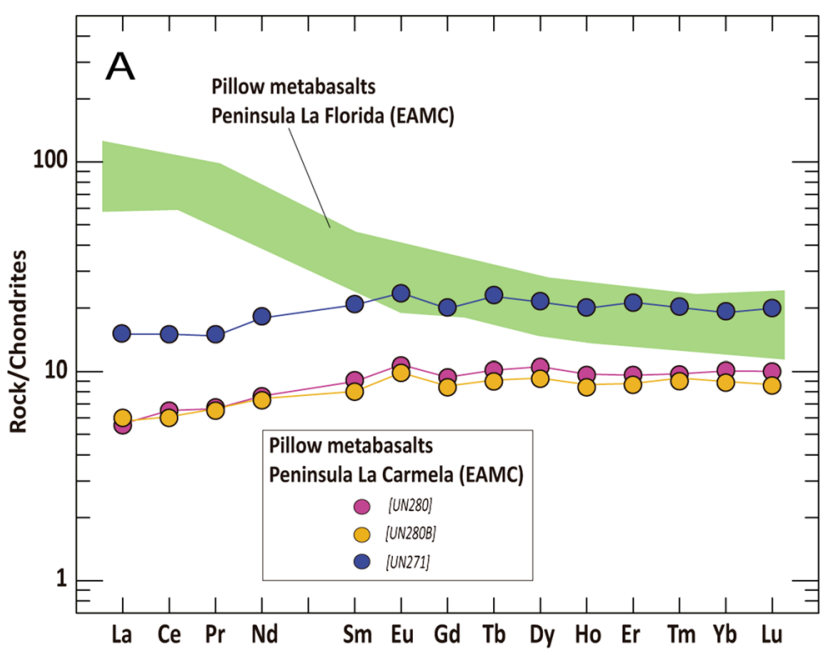

Fig. 5 A Chondrite-normalized REE patterns; B N-MORB normalized incompatible element patterns of metabasalts from Peninsula $\mathrm{La}$ Carmela. Normalizing values are from Sun and McDonough (1989).

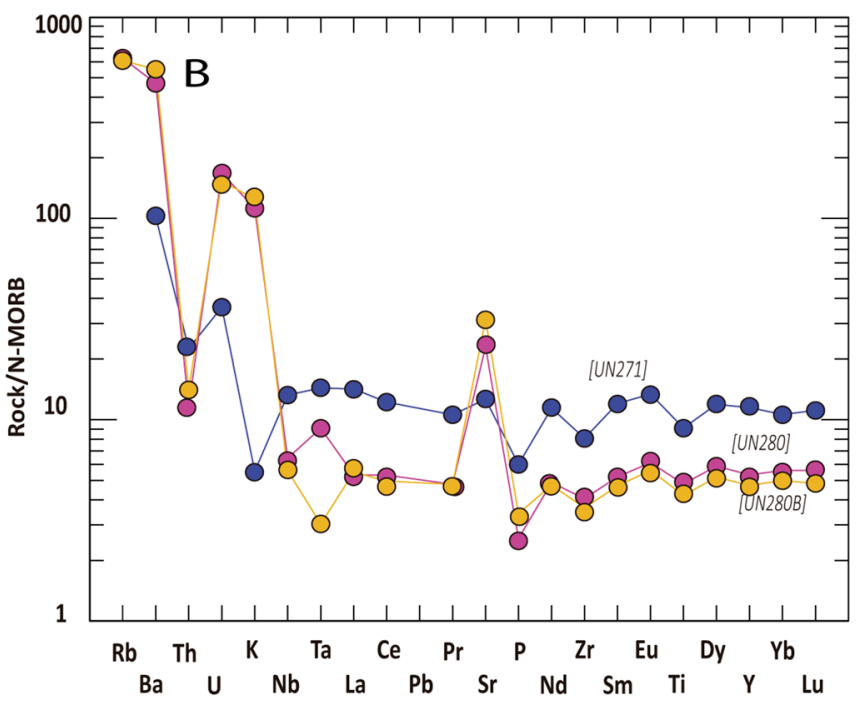

Pillow basalt EAMC of the Peninsula La Florida reported by Hervé et al. (1999) 

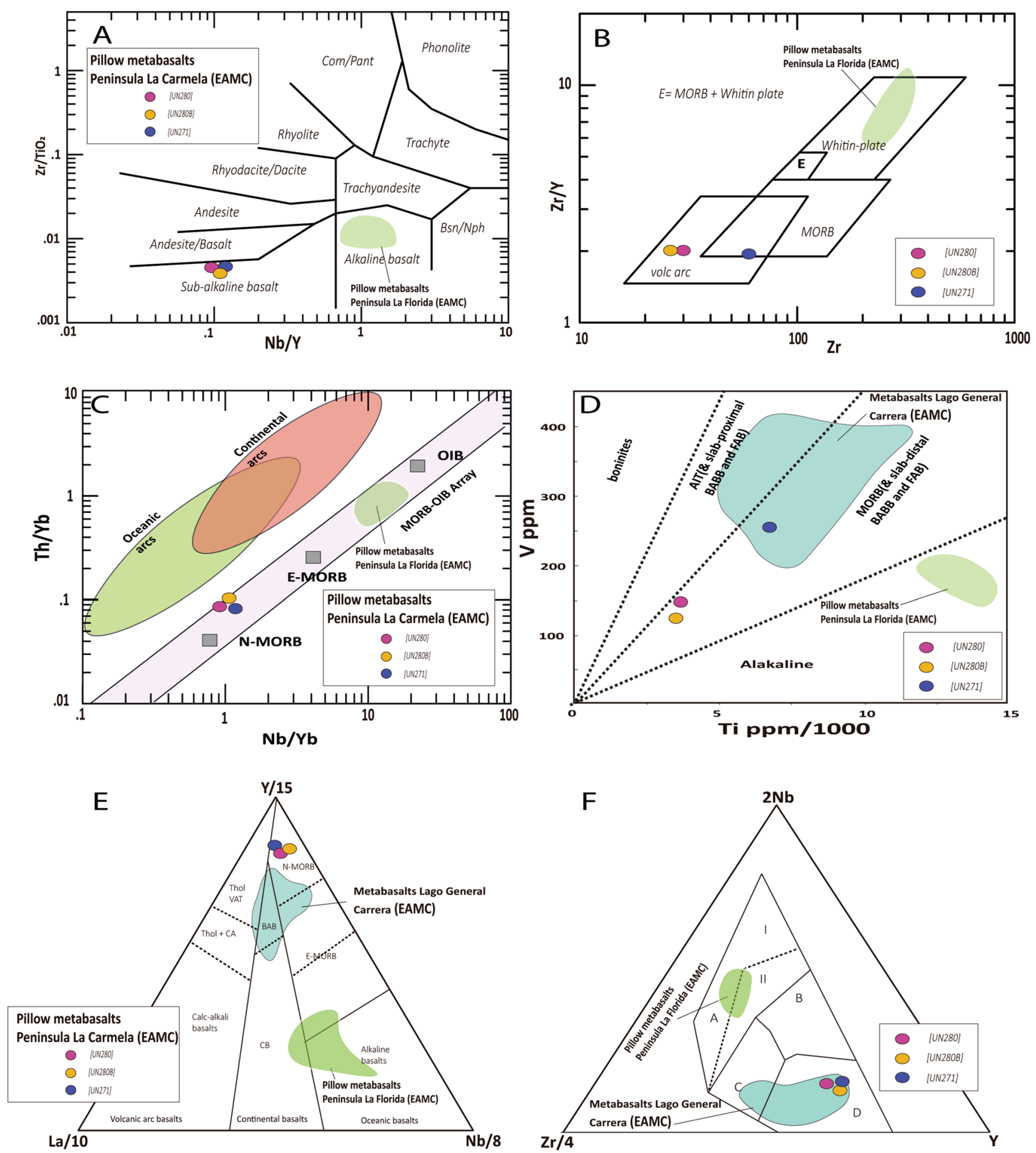

Fig. 6 A Classification of the metabasic rocks using the $\mathrm{Zr} / \mathrm{TiO}_{2}$ vs. $\mathrm{Nb} / \mathrm{Y}$ diagram of Winchester and Floyd (1977); B tectonic discrimination diagram using $\mathrm{Zr}$ vs. $\mathrm{Zr} / \mathrm{Y}$ (after Pearce and Norry, 1979); $\mathbf{C}$ $\mathrm{Th} / \mathrm{Yb}$ vs. Nb/Yb diagram (the field of the MORB-OIB mantle array is from Pearce, 2008); D tectonic discrimination diagrams for the metabasaltic rocks from the La Carmela and La Florida pillow bodies in V-Ti/1000 diagram (after Shervais, 1982); E Y/15-La/10-Nb/8

ternary diagram (after Cabanis and Lecolle, 1989 and $\mathbf{F} 2 \mathrm{Nb}-\mathrm{Zr} / 4$ $\mathrm{Y}$ ternary diagram (AI+AII: within-plate alkaline basalt; $\mathrm{AII}+\mathrm{C}$ : within-plate tholeiitic basalt; B: E-MORB; C+D: volcanic arc basalt; D: N-MORB;after Meschede, 1986). The diagrams are complemented with data from Hervé et al. (1999) and Quiroz and Belmar, 2010 
Fig. 7 Whole-rock isotopic $\left({ }^{87} \mathrm{Sr} /{ }^{86} \mathrm{Sr}\right) \mathrm{i}$ vs. $\varepsilon \mathrm{Nd}(\mathrm{t})$ diagram for the meta-pillowbasalts from Peninsula La Carmela and complemented with the metasedimentary rocks of EAMC from Augustsson and Bahlburg (2008)

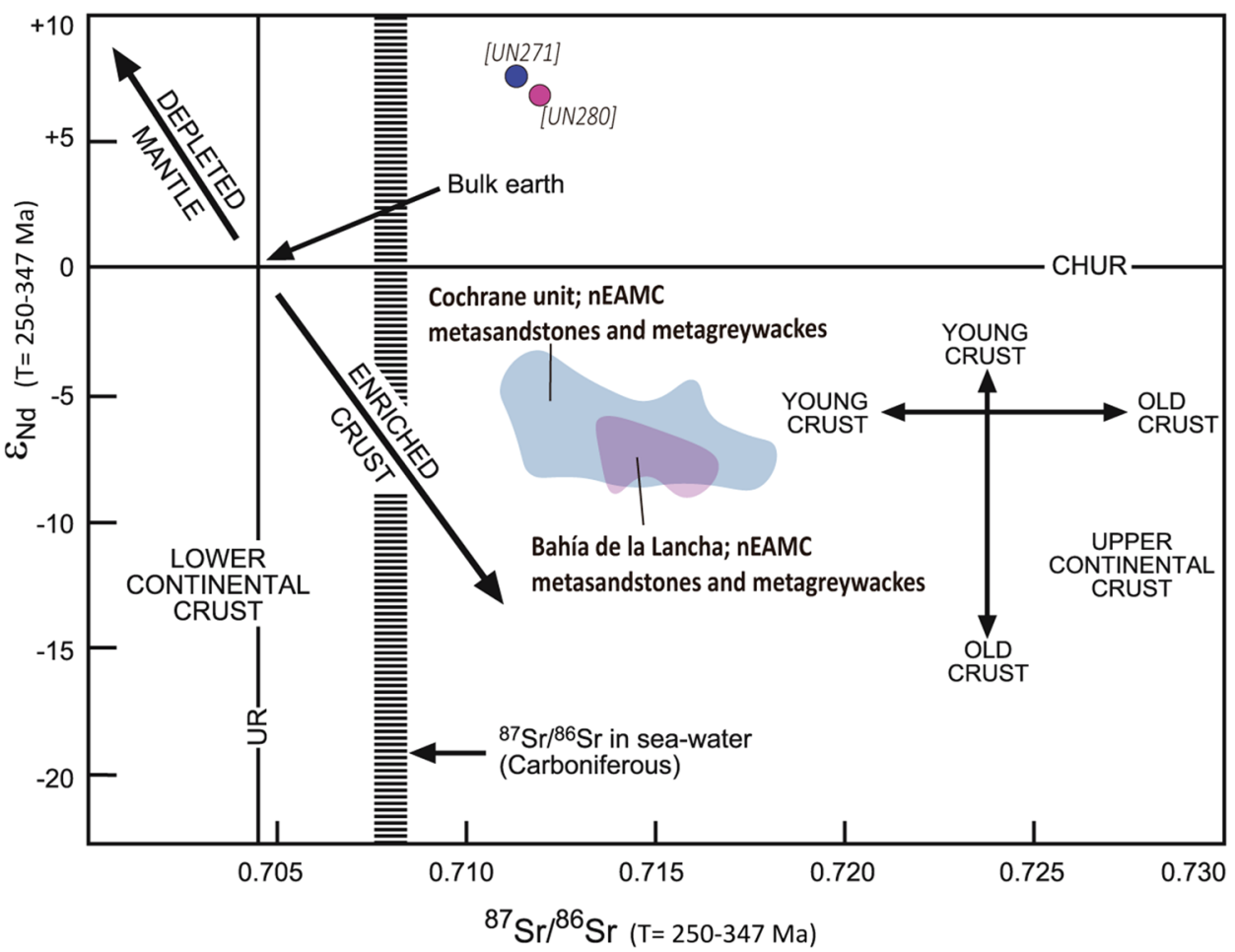

\section{Discussion}

\section{Provenance sources}

The probability density plot of metasedimentary rocks at Península La Carmela and surrounding Andean and extraAndean areas (Hervé et al. 2003; Augustsson et al. 2006; Malkowski et al. 2016) show a broad detrital zircon age spectrum (Fig. 8A-E). Outcrops at Lago O’Higgins-San Martin show main peaks of Neoproterozoic and Mesoproterozoic ages, with subordinate Archean components, and isolated Paleozoic grains (Fig. 8B-G; Hervé et al. 2003; Augustsson et al. 2006; Moreira et al. 2013; Permuy-Vidal et al. 2014; Malkowski et al. 2016; Suárez et al. 2019a). However, it turns out to be different to rocks from the Cerro Negro Schists, located in the western Deseado Massif that exhibits scarce Proterozoic zircons (Fig. 8F), and from the Nunatak Vietma Unit, which is characterized by Upper Triassic zircons (Fig. 8A) that can be considered as a different tectonic unit.

The sedimentary sources for protolith of the EAMC are still uncertain, since several sources have been invoked to explain these variable ages spectra (Hervé et al. 2003; Augustsson et al. 2006, 2008). At the time of deposition (Fig. 9), the closest autochthonous ancient sources from South America correspond to the Proterozoic Río de la Plata Craton (e.g., Tandilia Belt) and Pampia Terrane (Ramos 2009; Rapela et al., 2007; Cingolani 2011; Ramos et al. 2014). Nevertheless, these sources cannot explain the subordinate presence of Archean grains ( $>2.5 \mathrm{Ga}$ ) reported in the metasedimentary rocks from Península La Carmela as well in the whole EAMC (Fig. 8). The closest Archean region in South America correspond to the Nico Pérez Terrane (in Uruguay), that comprises a separate fragment of the Congo Craton (Oriolo et al. 2016). In this context, a set of Archean-Paleoproterozoic sources can be found surrounding the Dom Feliciano Belt, which corresponds to amalgamated craton blocks from South America and Africa during the Brasiliano/Pan-African orogeny (ca. 900-500 Ma) (Oriolo et al. 2016). Thus, the Nico Pérez Terrane in Uruguay and the Kalahari Craton from Africa (De Wit et al. 1992; Poujol et al. 2003) are possible candidates to explain the origin the subordinate Archean grains (Fig. 9). The Grenville zircons $(1.0-1.2 \mathrm{Ga})$ could have been sourced from the NamaquaNatal Complex in southern Africa (Eglington 2006), Gariep Belt, Malvinas/Falkland Islands (Jacobs et al. 1999), or Pampia Terrane (Western Sierra Pampeanas; Ramos et al. 2014 and their references) (Fig. 9). The Late Neoproterozoic-early Cambrian zircon grains (550-650 Ma) could be associated with the Cape Granite in South Africa (Scheepers and Armstrong 2002), Tierra del Fuego Igneous-Metamorphic Complex (Hervé et al. 2010), Pampia Terrane (Eastern Sierras Pampeanas; Ramos et al. 2014 and their references) or the crystalline basement of the Ventania System, where recently some Brasiliano/Pan African crystallization ages have been reported (Ballivián Justiniano et al. 2020). The most likely 
Fig. 8 Probability density plot showing relative probability ages of detrital zircons from different metamorphic localities of the, A Nunatak Unit (Suárez et al. 2019a); B Bahía de la Lancha (Augutsson et al. 2006); C La Carmela Peninsula (this work); D EAMC (Malkowski et al. 2016); E EAMC (Hervé et al. 2003); F Cerro Negro Schist (Permuy-Vidal et al. 2014); G La Modesta Formation (Moreira et al. 2013)
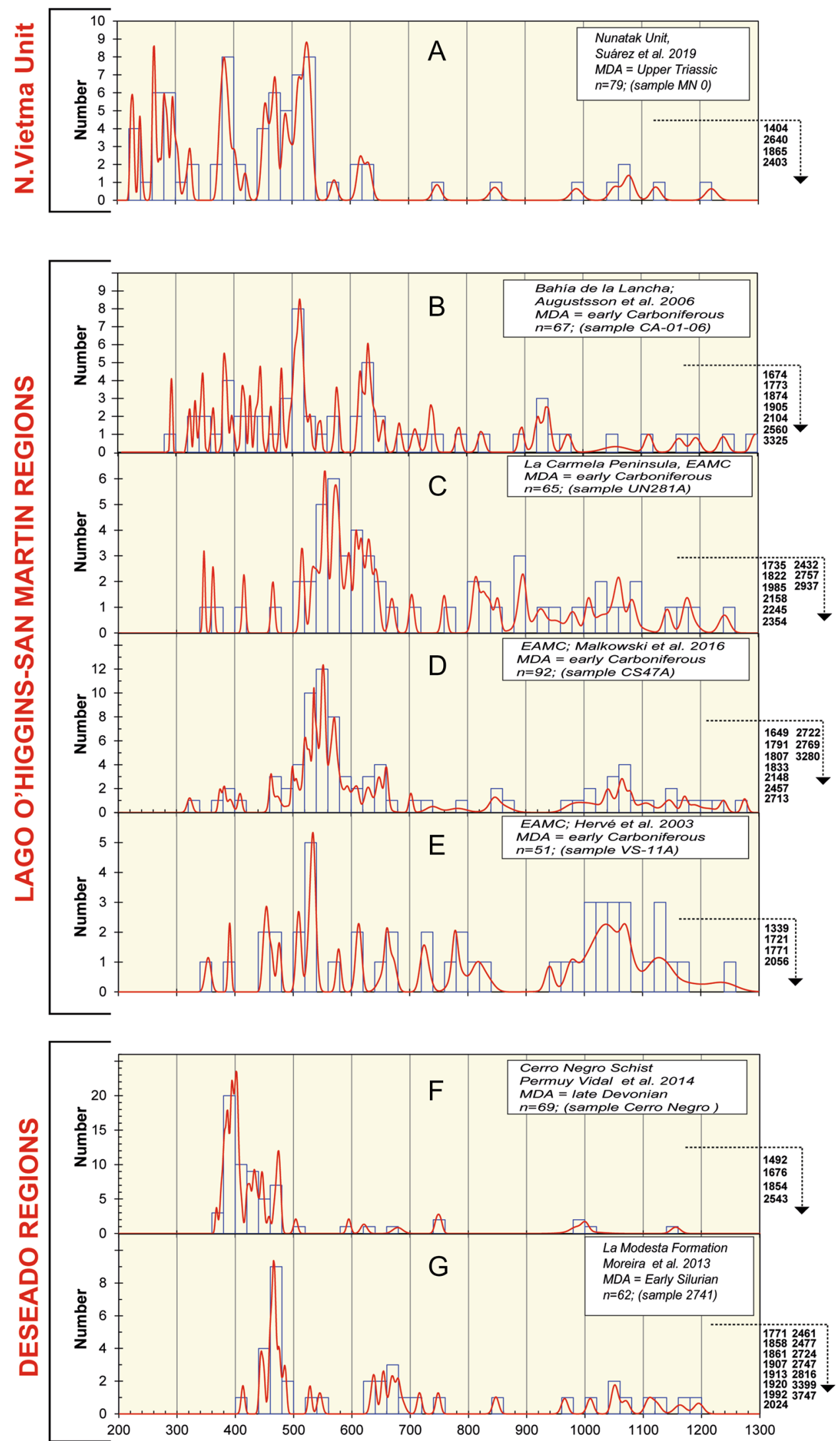


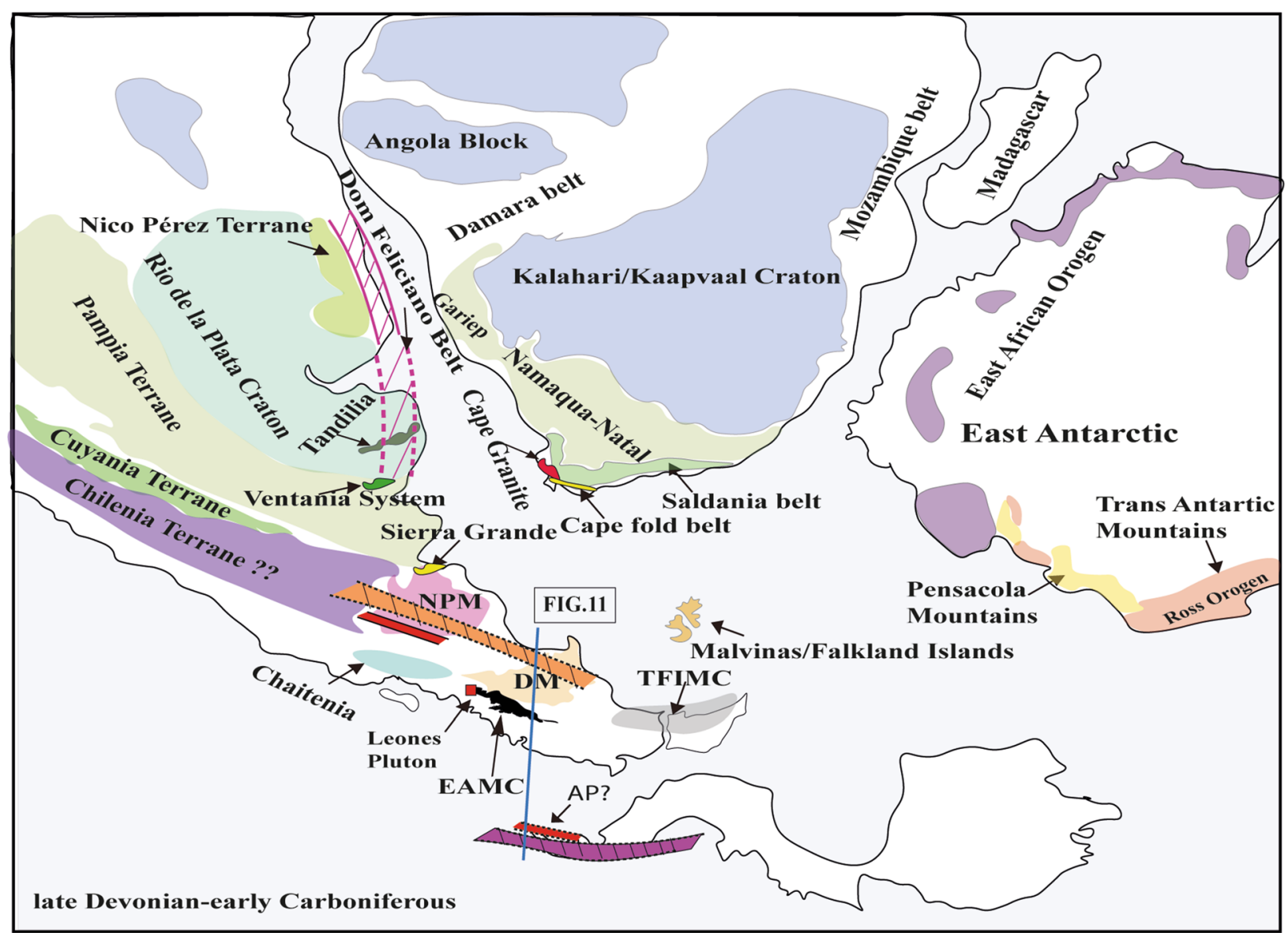

\begin{tabular}{|c|c|c|}
\hline Archean - Paleoproterozoic & \multicolumn{2}{|c|}{ Mesoproterozoic-Paleozoic } \\
\hline $\begin{array}{l}\sim 3.5-2.6 \mathrm{Ga}- \\
\text { Kalahari/Kaanvaal Craton }\end{array}$ & $\begin{array}{l}\sim 1.2-1.0 \mathrm{Ga}- \\
\sim\end{array}$ & $\begin{array}{l}0.56-0.52 \mathrm{Ga}- \\
\text { Pampia Terrane }\end{array}$ \\
\hline $\begin{array}{l}\sim 3.4-1.7 \text { Ga - } \\
\text { Nico Pérez Terrane }\end{array}$ & $\begin{array}{l}\sim 1.2-1.0 \mathrm{Ga}- \\
\text { Pampia Terrane }\end{array}$ & $\begin{array}{l}\text { (Eastern Sierras Pampeanas) } \\
0.52-0.30 M a- \\
\text { North Patagonian Massif (NPM) }\end{array}$ \\
\hline $\begin{array}{l}\sim 2.2 \text { - } 2.0 \mathrm{Ga}- \\
\text { Rio de la Plata Craton }\end{array}$ & $\begin{array}{l}\text { (Western Sierras Pampeanas) } \\
0.90-0.50 \mathrm{Ma}-\end{array}$ & $\begin{array}{l}\text { 0.54-0.52 Ga- } \\
\text { Tierra del Fuego (TFIMC) }\end{array}$ \\
\hline $\begin{array}{l}\sim 2.2-2.0 \mathrm{Ga}- \\
\text { Tandilia belt }\end{array}$ & $\begin{array}{l}\text { Crystalline Basement of } \\
\text { Ventania System }\end{array}$ & $\begin{array}{l}0.46-0.35 \text { Ga- } \\
\text { Deseado Massif (DM) }\end{array}$ \\
\hline $\begin{array}{l}\text { Silurian-Devonian } \\
\text { Magmatic Arc (425-358 Ma) }\end{array}$ & $\begin{array}{l}\text { boniferous } \\
\text { gmatic Arc ? }\end{array}$ & $\begin{array}{l}\text { ian-Triassic } \\
\text { smatic Arc (298 - } 230 \mathrm{Ma})\end{array}$ \\
\hline
\end{tabular}

Fig. 9 Paleogeographic sketch modified after Uriz et al. (2011), showing the possible main supply sources feeding material for EAMC at La Carmela Peninsula. The recompilation ages were obtained from works cited in Sect. "Provenance sources"

possibility to explain the subordinate older zircon grains, is that the supply regions are old metasedimentary complexes (e.g., La Modesta Formation, Rio Deseado Complex; Pankhurst et al. 2003; Guido et al. 2004; Moreira et al. 2013) from the Deseado Massif. If so, reworking of previous metasedimentary complexes would solve the problem posed by the great distances between the cratonic source areas and the basin, which is coherent with the model proposed by Suárez et al. (2019b).

However, the Silurian-Devonian to early Carboniferous zircon grains reported at Península La Carmela would have been derived from southern South America. We consider that the potential sources could be associated with the Silurian-early Carboniferous magmatic arc ( 425-340 Ma), that 

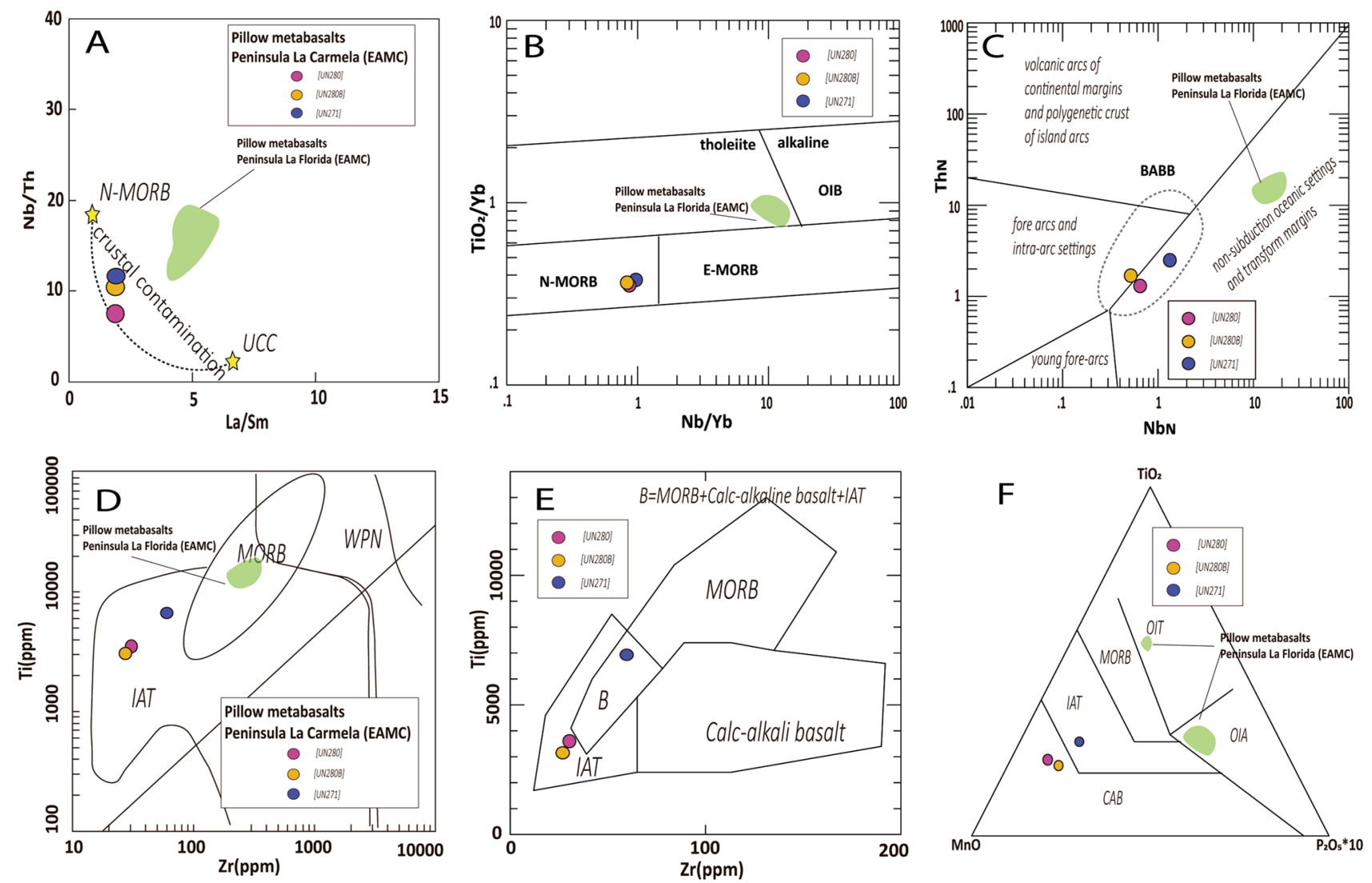

Fig. 10 Tectonic discrimination diagrams for meta-pillowbasalts from Lago O'Higgins-San Martín. A $\mathrm{Nb} / \mathrm{Th}$ vs. $\mathrm{La} / \mathrm{Sm}$ diagram showing the crustal contamination/assimilation influence. N-MORB: normal mid-ocean ridge basalt; UCC: upper continental crust. The end members compositions are after Sun and McDonough (1989); B

is partially exposed in the Deseado Massif (e.g., El Sacrificio Granite, El Laurel Tonalite, Bahía Laura Granodiorite) and North Patagonian Massif (e.g., Lago Lolog Granite, Caceres Granite, Cordon El Serrucho) (e.g.,Guido et al. 2004; Pankhurst et al. 2003, 2006; Varela et al. 2015; Hervé et al. 2016). Therefore, we considered that the maximum depositional age is concordant with mid-late Paleozoic regional geological background.

\section{Petrogenesis of the pillow metabasalts}

The use of immobile trace elements coupled with $\mathrm{Sr}-\mathrm{Nd}$ isotope data can be employed to characterize parental magma source and thus shed light to elucidate the tectonic setting on which these magmas were formed (Pearce and Cann 1973; Shervais 1982; Cabanis and Lecolle 1989; Saunders and Tarney 1984; Pearce 2008, 2014). The basalts have been widely used to unravel the tectonic setting of magma generation due their simpler petrogenesis when compared with andesites and granites (Xia and $\mathrm{Li}$
$\mathrm{Nb} / \mathrm{Yb}$ vs. $\mathrm{TiO} 2 / \mathrm{Yb}$ (Pearce 2008); $\mathbf{C} \mathrm{Th}_{\mathrm{N}}$ vs. $\mathrm{Nb}_{\mathrm{N}}$ diagrams (Saccani 2015), $\mathrm{Nb}$ and Th are normalized to the N-MORB composition (Sun and McDonough 1989); D Ti-Zr diagram (after Pearce 1980); E tectonic diagram using $\mathrm{Zr}$ vs. Ti (Pearce and Cann 1973). F TiO2MnO*10-P2O5*10 (after Mullen 1983)

2019). We discuss the petrogenesis of the pillow metabasalts from Península La Carmela based on the new geochemical and isotopic data, complemented with previous data from pillow metabasalts exposed in the surrounding areas of the Lago O'Higgins-San Martín. Previously analyzed metabasalts at Península La Florida, located $20 \mathrm{~km}$ northeast of the Península La Carmela, are also tectonically juxtaposed with metasedimentary sequences of the EAMC (Hervé et al. 1999) (Fig. 1). Because the chemical composition of metabasalts from Península La Carmela was variably modified by seafloor hydrothermal processes the data presentation will be centered in low mobility elements (Ti, V, Y, Zr, Nb, Th, REE; cf. Furnes et al. 2020 and references therein).

Cui et al. (2020) mentioned that $\mathrm{Nb} / \mathrm{Th}$ and $\mathrm{La} / \mathrm{Sm}$ ratios are good discriminators to know the degree of crustal contamination. In this case, our pillow metabasalts as well as those at Península La Florida do not follow the hyperbolic mixing curve, plotting away from upper continental crust field (Fig. 10A). Analogously, the pillow 
Fig. 11 Tectonic setting interpretation for the genesis of the pillow metabasalts from Lago O’Higgins-San Martín. AP: Antarctic Peninsula?. Modified after Rojo et al. (2021) late Devonian-Carboniferous

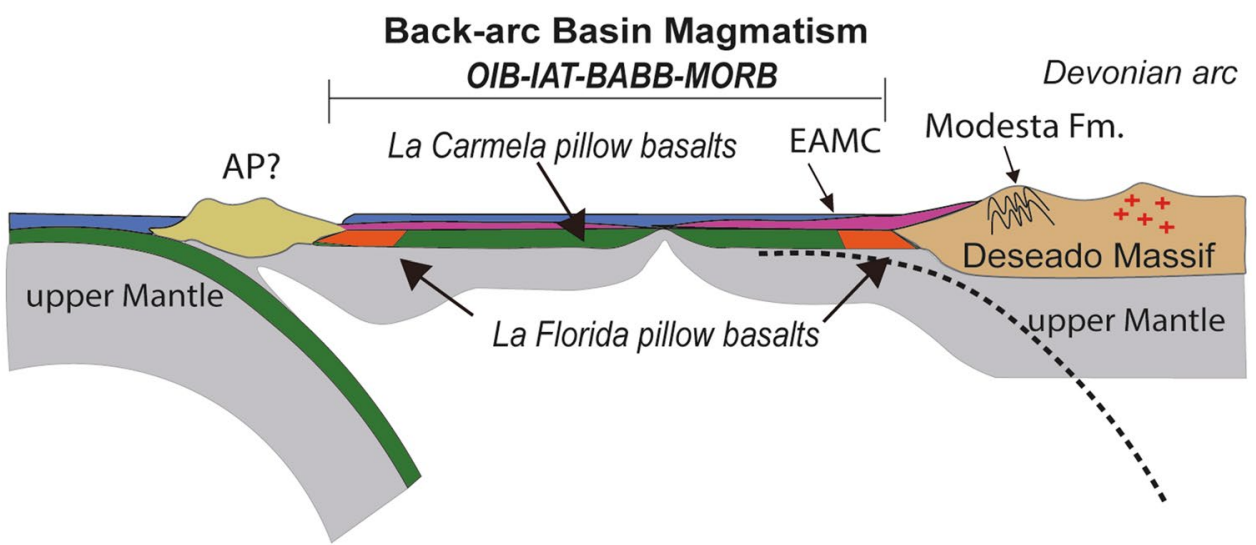

metabasalts from the Península La Carmela have $\mathrm{Zr}$ (27-60 ppm), Th (0.14-0.27 ppm) and Hf (0.8-1.8 ppm) values, indicating a poor or little modified depleted mantle source (Table 1).

The depth of the mantle melting can be constrained by the $\mathrm{TiO}_{2} / \mathrm{Yb}$ ratios, where the ocean island basalt (OIB) signature is associated to a deep mantle source, while the MORB-signature is related to the shallow depth of the melting source (Pearce 2014) in a spreading ridge. Metabasalt bodies at Península La Carmela have a N-MORB signature and low $\mathrm{TiO}_{2} / \mathrm{Yb}$ values signaling a shallow melting source (Fig. 10B), while the metabasalts at Península La Florida show OIB chemical affinities suggesting deeper zones of mantle melting zones (Fig. 10B). Another valuable proxy to discriminate between a depleted or enrichment nature source of basic rocks is the $\mathrm{Zr} / \mathrm{Nb}$ ratio (Pearce and Norry 1979). Our samples have low Nb (1.3-3.1 ppm), Zr (27-60 ppm), Ba (64-347 ppm), and shown low $\mathrm{Zr} / \mathrm{Nb}$ ratios (19.35-20.80) concerning average N-MORB ( $\mathrm{Zr} / \mathrm{Nb}:>301$; Sun and McDonough 1989).

The $\mathrm{Th}_{\mathrm{N}}$ vs. $\mathrm{Nb}_{\mathrm{N}}$ diagram (N-MORB normalized) (Saccani 2015) was used to evaluate or discard the influence of subduction components in the geochemistry of metabasalts. The pillow metabasalts from Península La Carmela plot in the field of back-arc basin basalts (BABB) with $\mathrm{Th}_{\mathrm{N}}$ (1.4-2.5) and $\mathrm{Nb}_{\mathrm{N}}(0.55-1.33)$ values (Fig. 10C), while those at Península La Florida plot in the non-subduction oceanic settings. In general, the mafic bodies showing N-MORB signatures with subduction-related affinities indicate oceanic spreading in a supra-subduction zone, as well as back-arc and fore-arc basins and/or rifted island arcs (e.g., Metcalf and Shervais 2008). The lack of bonninites allow suggest a back-arc basin environment to explain the presence of basaltic products with N-MORB, BABB and IAT geochemical signatures (Fig. 10D-F) (e.g., Clai et al., 2020). The $\mathrm{Sr}-\mathrm{Nd}$ isotopic data give clues about the source of the parental magmas. The high ${ }^{87} \mathrm{Sr} /{ }^{86} \mathrm{Sr}$ initial ratios $(>0.710)$ of metabasalts at Península La Carmela can be associated with significant crustal assimilation in the magmatic system or seawater alteration (McCulloch et al. 1981). In our study case the crustal contamination is ruled out (as previously discussed; see Fig. 10A) and thus the radiogenic ${ }^{87} \mathrm{Sr} /{ }^{86} \mathrm{Sr}$ initial ratios are likely related to processes of seawater alteration with or without modification during a later metamorphic event. Besides, the high $\varepsilon N d(t=350 \mathrm{Ma})$ values of +6 to +7.5 and trace element composition reveal the derivation of basaltic magmas from a depleted mantle source in a supra-subduction setting.

Considering that metabasalts at Península La Florida have OIB chemical affinities (Fig. 6), like those reported in plateau basalt provinces in southern South America, suggests a similar Gonwanide lithospheric mantle source of basaltic magmas. We propose that OIB magmatism occurred during embryonic stages of the back-arc basin formation.

\section{Paleogeographic and tectonic implications}

The depositional environment for the protolith of the prePermian EAMC has been traditionally interpreted as a passive margin (Augustsson and Balhburg, 2003, 2008). However, petrographic, geochronologic, geochemical and metamorphic $\mathrm{P}-\mathrm{T}$ conditions support the existence of an active margin located in southwestern Gondwana margin during mid-Paleozoic to Late Triassic times (Ramos 2008; Permuy Vidal et al., 2014; Rojo 2017; Suárez et al. 2019a; Navarrete et al. 2019; Rojo et al. 2021). An active margin during Silurian-Devonian times associated with a magmatic arc (425-393 Ma) in extra-Andean Patagonia is supported by small and isolated outcrops of arc-related granitoid rocks (e.g., El Sacrificio, El Laurel, and Bahia Laura; Pankhurst et al. 2003; Guido et al. 2004, 2005). During Carboniferous times, the locus of arc magmatism migrated to the west of the EAMC (cf. Rojo et al. 2021), whereas during the Permian to Late Triassic (287-227 Ma) the magmatic activity 
shifted to the Antarctic Peninsula (Graham Land and Palmer Land) (Millar et al. 2002; Suárez et al. 2019a; Bastías et al. 2020), which at that time is thought to have been located to the west of Patagonia (Fig. 9).

Therefore, considering an early Carboniferous maximum depositional age for the protolith of metasedimentary sequences at Península La Carmela and a nearly coeval emplacement of the pillow metabasalts, derived from a depleted upper mantle source (high positive eNd values) with low or null crustal contamination in a subduction environment with an IAT and BABB signatures. We consider a back-arc basin scenario to explain the geochemical and isotopic features shown by the metabasalts from Lago O’Higgins-San Martín. The early magmatic activity during the back-arc basin formation may have been represented by oceanic island basalts at Península La Florida and the most mature products are represented by metabasalts with MORB, IAT and BBAB geochemical affinities located at Península La Carmela. This regional geodynamic configuration suggests the development of an active back-arc basin to west of the Deseado Massif, generated in response to the westward drift of the Antarctic Peninsula relative to southwestern Gondwana margin, during late Paleozoic times (Fig. 11). The tectonic juxtaposition of metasedimentary rocks and metabasalts occurred probably within an accretionary wedge developed during the back-arc basin closure and docking of Antarctic Peninsula.

\section{Conclusions}

The detrital zircon ages obtained in this study suggest an early Carboniferous ( $347 \mathrm{Ma}$ ) maximum depositional age for the protolith of metasedimentary rocks at Península La Carmela. The oldest detrital zircon grains indicate provenance from regions with rocks of 555 to $620 \mathrm{Ma}, 880 \mathrm{Ma}$ and 1.0-1.2 Ga. The subordinated oldest detrital zircons derive from either (i) close regions of Gondwana (e.g., Nico Pérez Terrane, Rio de la Plata Craton, Pampean belts, Ventania System, Tierra del Fuego Igneous-Metamorphic Complex), (ii) distant regions (e.g., Kalahari craton, Namaqua Natal Complex, Gariep Belt, Malvinas/Falkland Islands, Cape Granite) or (iii) reworked material from ancient metasedimentary rocks from Argentine Patagonia (e.g., La Modesta Formation, Río Deseado Complex). The Silurian-Devonian zircon grains derived from southern South America (North Patagonian Massif and Deseado Massif).

The basaltic magmatism at Península La Carmela in the Lago O’Higgins-San Martín, derived from a depleted mantle source with low or null degree of crustal contamination, with N-MORB, IAT and BABB signatures, emplaced within a mature back-arc basin, coeval with the sedimentation of turbidites of the EAMC. The tectonic juxtaposition of metasedimentary rocks and metabasalts is related to the closure of the back-arc basin during the Gondwanide orogeny.

Acknowledgements The authors would like to thank Dr. Mark Fanning for performing the geochrological analysis of zircons, as well as the support and assistance of the Ciencia Joven program of the Instituto Chileno de Campos de Hielo. Dayvi Mancilla is acknowledged for their hospitality and assistance during the fieldwork at Península La Carmela and Villa O'Higgins. This research has been funded by Fondecyt projects 1161818 (MC) and 1180457 (FH). The manuscript was highly benefited by the suggestions of Dr. Sebastian Oriolo and an anonymous reviewer. Likewise, we are grateful to the associate editor for editorial assistance.

\section{References}

Augustsson C, Bahlburg H (2003) Active or passive margin? Geochemical and $\mathrm{Nd}$ isotope constraints of metasediments in the backstop of a pre-Andean accretionary wedge in southernmost Chile $\left(46^{\circ} 30^{\prime}-48^{\circ} 30^{\prime} \mathrm{S}\right)$, In: Tracing tectonic deformation using the sedimentary record, McCann T, Saintot A (eds). Geol Soc Spec Publ 208:253-268.

Augustsson C, Bahlburg H (2008) Provenance of late Paleozoic metasediments of the Patagonian proto-Pacific margin (southernmost Chile and Argentina). Int J Earth Sci 97:71-88. https:// doi.org/10.1007/s00531-006-0158-7

Augustsson C, Münker C, Bahlburg H, Fanning M (2006) Provenance of late Palaeozoic metasediments of the SW South American Gondwana margin: a combined U-Pb and Hf-isotope study of single detrital zircons. J Geol Soc Lond 163:983-995. https://doi.org/10.1144/0016-76492005-149

Ballivián Justiniano CA, Basei M, Sato A, González P, Benítez M, Lanfranchini M (2020) The Neoproterozoic basement of the Sauce Chico Inlier (Ventania System): geochemistry and U-Pb geochronology of igneous rocks with African lineage in centraleastern Argentina. J South Am Earth Sci. https://doi.org/10. 1016/j.jsames.2019.102391

Bastias J, Spikings R, Ulianov A, Riley T, Burton-Johnson A, Chiaradia M, Baumgartner L, Hervé F, Bouvier AS (2020) The Gondwanan margin in West Antarctica: Insights from Late Triassic magmatism of the Antarctic Peninsula. Gondwana Res 81:1-20. https://doi.org/10.1016/j.gr.2019.10.018

Cabanis B, Lecolle M (1989) Le diagramme La/10, Y/15, Nb/8: un outil pour la discrimination des series volcaniques et la mise en evidence des processus de melanges et/ou de contamination crustale. Comptes Rendus Académie Sciences 309:2023-2029

Calderón M, Hervé F, Massonne H-J, Tassinari CG, Pankhurst RJ, Godoy E, Theye T (2007) Petrogenesis of the Puerto Edén Igneous and Metamorphic Complex, Magallanes, Chile: Late Jurassic syn-deformational anatexis of metapelites and granitoid magma genesis. Lithos 93:17-38. https://doi.org/10.1016/j. lithos.2006.03.044

Calderón M, Hervé F, Fuentes F, Fosdick JC, Sepúlveda F, Galaz G (2016) Tectonic Evolution of Paleozoic and Mesozoic Andean Metamorphic Complexes and the Rocas Verdes Ophiolites in Southern Patagonia. In: Geodynamic Evolution of the Southernmost Andes, Ghiglione MC (eds). Springer Earth System Sciences. doi: https://doi.org/10.1007/978-3-319-39727-6_2.

Castillo P, Fanning MC, Hervé F, Lacassie JP (2016) Characterization and tracing of Permian magmatism in the south-western segment of the Gondwanan margin; $\mathrm{U}-\mathrm{Pb}$ age, $\mathrm{Lu}-\mathrm{Hf}$ and $\mathrm{O}$ isotopic compositions of detrital zircons from metasedimentary complexes of 
northern Antarctic Peninsula and western Patagonia. Gondwana Res 36:1-13. https://doi.org/10.1016/j.gr.2015.07.014

Cingolani C (2011) The Tandilia System of Argentina as a southern extension of the Río de la Plata craton: an overview. Int J Earth Sci 100:221-242. https://doi.org/10.1007/s00531-010-0611-5

Copeland P (2020) On the use of geochronology of detrital grains in determining the time of deposition of clastic sedimentary strata. Basin Res 00:1-15. https://doi.org/10.1111/bre.12441

Cui X, Sun M, Zhao G, Yao J, Zhang Y, Han Y, Dai L (2020) A Devonian arc-back-arc basin system in the southern Chinese Altai: Constraints from geochemical and $\mathrm{Sr}-\mathrm{Nd}-\mathrm{Pb}$ isotopic data for meta-basaltic rocks. Lithos Volumes. https://doi.org/10.1016/j. lithos.2020.105540

De La Cruz R, Suárez M (2006) Geología del área Puerto GuadalPuerto Sánchez, Región Aisén del General Carlos Ibáñez del Campo, Escala 1:100.000, Carta Geológica de Chile, Serie Geología Básica, No 95. Servicio Nacional de Geología y Minería, Santiago, Chile.

De La Cruz R, Welkner D, Suárez M, Quiroz D (2004) Geología del área oriental de las hojas Cochrane y Villa O'Higgins, Región Aisén del General Carlos Ibáñez del Campo, escala 1:250.000, Carta Geológica de Chile, Serie Geología Básica, No 85. Servicio Nacional de Geología y Minería, Santiago, 75 Chile.

De Wit MJ, de Ronde CE, Tredoux M, Roering C, Hart RJ, Armstrong RA, Hart RA (1992) Formation of an Archaean continent. Nature 357:553-562. https://doi.org/10.1038/357553a0

Dickinson WR, Gehrels GE (2009) Use of U-Pb ages of detrital zircons to infer maximum depositional ages of strata: a test against a Colorado Plateau Mesozoic database. Earth Planet Sci Lett 288:115-125. https://doi.org/10.1016/j.eps1.2009.09.013

Du Toit AL (1927) A geological comparison of South America with South Africa. Publications Carnegie Institute, Washington, D.C.

Eglington BM (2006) Evolution of the Namaqua-Natal Belt, southern Africa-a geochronological and isotope geochemical review. J Afr Earth Sci 46:93-111. https://doi.org/10.1016/j.jafrearsci.2006. 01.014

Forsythe R, Mpodozis C (1979) El Archipiélago Madre de Dios, Patagonia occidental, Magallanes: rasgos generales de la estratigrafía y estructura del basamento pre-Jurásico Superior. Revista Geológica De Chile 7:13-29

Furnes H, Dilek Y, Zhao G, Safonova J, Santosh M (2020) Geochemical characterization of ophiolites in the Alpine-Himalayan Orogenic Belt: magmatically and tectonically diverse evolution of the Mesozoic Neotethyan oceanic crust. Earth Sci Rev. https://doi.org/ 10.1016/j.earscirev.2020.103258

Gehrels G, Valencia V, Pullen A (2006) Detrital zircon geochronology by laser ablation multicollector ICPMS at the Arizona LaserChron Center. In: Geochronology: Emerging opportunities, Olszewski T (eds). Paleontology Society Papers 12:67-76. doi: https://doi.org/ $10.1017 / \mathrm{S} 1089332600001352$.

Giacosa R, Márquez M (2002) El basamento paleozoico de la Cordillera Patagónica. In: Geología y Recursos Naturales de Santa Cruz, Haller MJ (eds). Congreso Geológico Argentino Calafate 1:45-55.

Giacosa R, Fracchia D, Heredia N (2012) Structure of the Southern Patagonian Andes at $49^{\circ} \mathrm{S}$, Argentina. Geol Acta 10:265-282

Godoy E (1979) Metabasitas del basamento metamórfico chileno: nuevos datos geoquímicos. Actas 2nd Congreso Geológico Chileno 3:133-143.

Guido D, Escayola MP, Schalamuk I (2004) The basement of the Deseado Massif at Bahía Laura, Patagonia, Argentina: a proposal for its evolution. J South Am Earth Sci 16:567-577. https://doi. org/10.1016/j.jsames.2003.10.003

Guido DM, Rapela CW, Pankhurst RJ, Fanning CM (2005) Edad del granito del alforamiento Bahía Laura, Macizo del Deseado, provincia de Santa Cruz. Actas $16^{\circ}$ Congreso Geológico Argentino La Plata CD ROM 85-88.
Hervé F, Pankhurst RJ, Drake R, Beck M (1995) Pillow metabasalts in a mid-Tertiary extensional basin adjacent to the Liquiñe-Ofqui fault zone: the Isla Magdalena area, Aysén, Chile. J South Am Earth Sci 8:33-46. https://doi.org/10.1016/0895-9811(94)00039-5

Hervé F, Aguirre L, Godoy E, Massone H-J, Morata D, Pankhurst RJ, Ramírez E, Sepúlveda V, Willner A (1998) Nuevos antecedentes acerca de la edad y las condiciones P-T de los Complejos Metamórficos en Aysén, Chile. X Congreso Latinoamericano De Geología Buenos Aires 2:134-137

Hervé F, Sepúlveda V, Morata D (1999) Contrasting geochemistry and metamorphism of pillow basalts in metamorphic complexes from Aysen, S. Chile J South Am Earth Sci 12:379-388. https://doi.org/ 10.1016/S0895-9811(99)00029-2

Hervé F, Fanning CM, Pankhurst RJ (2003) Detrital zircon age patterns and provenance of the metamorphic complexes of southern Chile. J South Am Earth Sci 16:107-123. https://doi.org/10.1016/ S0895-9811(03)00022-1

Hervé F, Pankhurst RJ, Fanning CM, Calderón M, Yaxley GM (2007) The South Patagonian batholith: 150 my of granite magmatism on a plate margin. Lithos 97:373-394. https://doi.org/10.1016/j. lithos.2007.01.007

Hervé F, Calderón M, Faundez V (2008) The metamorphic complexes of the Patagonian and Fueguian Andes. Geological Acta 6:43-45. https://doi.org/10.1344/105.000000240

Hervé F, Calderón M, Fanning CM, Kraus S, Pankhurst R (2010) SHRIMP chronology of the Magallanes Basin basement, Tierra del Fuego: Cambrian plutonism and Permian high-grade metamorphism. Andean Geology 32:253-275. https://doi.org/10.5027/ andgeoV37n2-a01

Hervé F, Calderón M, Fanning CM, Pankhurst RJ, Fuentes F, Rapela CW, Correa J, Quezada P, Marambio C (2016) Devonian magmatism in the accretionary complex of southern Chile. J Geol Soc London 173:587-602. https://doi.org/10.1144/jgs2015-163

Jacobs J, Thomas RJ, Armstrong RA, Henjes-Kunst F (1999) Age and thermal evolution of the Mesoproterozoic Cape Meredith Complex, West Falkland. J Geol Soc 156:917-928. https://doi.org/10. 1144/gsjgs.156.5.0917

Lacassie JP (2003) Estudio de la Proveniencia Sedimentaria de los Complejos Metamórficos de los Andes Patagónicos $\left(46^{\circ}-51^{\circ} \mathrm{S}\right)$, mediante la aplicación de redes neuronales e isótopos estables. Doctoral thesis, Universidad de Chile.

Lagally U (1975) Geologische Untersuchungen mit Gebiet Lake General Carrera - Lake Cochrane, Prov. Aysen/Chile unter besonderer Berücksichtigung des Grundgebirges und seiner Tektonik. Dissertation, Universität München.

Ludwig KJ (2003) ISOPLOT 3.00: A geochronological toolkit for Microsoft Excel. Berkeley Geochronology Center.

Malkowski MA, Grove M, Graham SA (2016) Unzipping the Patagonian Andes- longlived influence of rifting history on foreland basin evolution. Lithosphere 8:23-28. https://doi.org/10.1130/L489.1

McCulloch MT, Gregory RT, Wasserburg G, Taylor HP Jr (1981) $\mathrm{Sm}-\mathrm{Nd}, \mathrm{Rb}-\mathrm{Sr}$, and $18 \mathrm{O} / 16 \mathrm{O}$ isotopic systematics in an oceanic crustal section: evidence from the Samail Ophiolite. J Geophys Res Solid Earth 86:2721-2735

Meschede M (1986) A method of discriminating between different types of mid-ocean ridge basalts and continental tholeiites with $\mathrm{Nb}-\mathrm{Zr}$-Y diagram. Chem Geol 56:207-218

Metcalf RV, Shervais JW (2008) Supra-Subduction Zone (SSZ) Ophiolites: is there really an "Ophiolite Conundrum"? In: Ophiolites, arcs, and batholiths: a tribute to Cliff Hopson, Wright JE, Shervais JW (eds). Geol Soc Am Spec Paper 438:191-222. doi: https://doi. org/10.1130/2008.2438(07).

Millar IL, Pankhurst RJ, Fanning CM (2002) Basement chronology of the Antarctic Peninsula: recurrent magmatism and anatexis in the Palaeozoic Gondwana Margin. J Geol Soc 159:145-157. https:// doi.org/10.1144/0016-764901-020 
Miyashiro A (1975) Classification, characteristics, and origin of ophiolites. J Geol 83:249-281. http://www.jstor.org/stable/30060218.

Moreira P, Fernández R, Hervé F, Fanning CM, Schalamuk I (2013) Detrital zircons U-Pb SHRIMP ages and provenance of La Modesta Formation, Patagonia Argentina. J South Am Earth Sci 47:32-46. https://doi.org/10.1016/j.jsames.2013.05.010

Mullen ED (1983) MnO/TiO2/P2O5: a minor element discriminant for basaltic rocks of oceanic environments and its implications for petrogenesis. Earth Planet Sci Lett 62:53-62

Muller V, Calderón M, Fosdick JC, Ghiglione MC, Cury LF, Massonne H-J, Fanning CM, Warren CJ, Ramírez de Arellano C, Sternai P (2021) The closure of the Rocas Verdes Basin and early tectonometamorphic evolution of the Magallanes Fold-and-Thrust Belt, southern Patagonian Andes (52-54S). Tectonophysics. https:// doi.org/10.1016/j.tecto.2020.228686

Navarrete C, Gianni G, Encinas E, Márquez M, Kamerbeek Y, Valle M, Folguera A (2019) Triassic to middle jurassic geodynamic evolution of southwestern Gondwana: from a large flat-slab to mantle plume suction in a rollback subduction setting. Earth Sci Rev 194:125-159. https://doi.org/10.1016/j.earscirev.2019.05.002

Oriolo S, Oyhantçabal P, Basei M, Wemmer K, Siegesmund S (2016) The Nico Pérez Terrane (Uruguay): from Archean crustal growth and connections with the Congo Craton to late Neoproterozoic accretion to the Río de la Plata Craton. Precambrian Res 280:147160. https://doi.org/10.1016/j.gr.2011.05.001

Oriolo S, Schulz B, González P, Bechis F, Olaizola E, Krause J, Renda E, Vizán H (2019) The Late Paleozoic tectonometamorphic evolution of Patagonia revisited: Insights from the pressure-temperature-deformation-time (P-T-D-t) path of the Gondwanide basement of the North Patagonian Cordillera (Argentina). Tectonics 38:2378-2400. https://doi.org/10.1029/2018TC005358

Oyhantcabal P, Siegesmund S, Wemmer K (2010) The Río de la Plata Craton: a review of units, boundaries, ages and isotopic signature. In: Multiaccretional tectonics at the Rio de la Plata Margins, Siegesmund S, Basei M, Oyhantcabal P (eds). Int J Earth Sci 100:201-220. doi: https://doi.org/10.1007/s00531-010-0580-8.

Pankhurst RJ, Weaver SD, Hervé F, Larrondo P (1999) MesozoicCenozoic of the North Patagonian Batholith in Aysen, southern Chile. J Geol Soc 156:673-694. https://doi.org/10.1144/gsjgs. 156.4.0673

Pankhurst RJ, Rapela CW, Loske W, Marquez M, Fanning CM (2003) Chronological study of the pre-Permian basement rocks of southern Patagonia. J S Am Earth Sci 16:27-44. https://doi.org/10. 1016/S0895-9811(03)00017-8

Pankhurst RJ, Rapela CW, Fanning CM, Márquez M (2006) Gondwanide continental collision and the origin of Patagonia. EarthSci Rev 76:235-257. https://doi.org/10.1016/j.earscirev.2006.02. 001

Pearce JA (2008) Geochemical fingerprinting of oceanic basalts with applications to ophiolite classification and the search for Archean oceanic crust. Lithos 100:14-48. https://doi.org/10.1016/j.lithos. 2007.06.016

Pearce JA (2014) Geochemical fingerprinting of the earth's oldest rocks. Geology 42:175-176. https://doi.org/10.1130/focus 022014.1

Pearce JA, Cann JR (1973) Tectonic setting of basic volcanic rocks determined using trace element analyses. Earth Planet Sci Lett 19:290-300. https://doi.org/10.1016/0012-821X(73)90129-5

Pearce JA, Norry MJ (1979) Petrogenetic implications of Ti, Zr, Y, and $\mathrm{Nb}$ variations in volcanic rocks. Contrib Mineral Petrol 69:33-47

Permuy-Vidal C, Moreira P, Guido DM, Fanning CM (2014) Linkages between the southern Patagonia Pre-Permian basements: new insights from detrital zircons U-Pb SHRIMP ages from the Cerro Negro District. Geological Acta 12:137-150
Pettijohn FP, Potter PE, Siever R (1973) Sand and sandstones. SpringerVerlag, New York-Heidelberg-Berlin, p 618

Poujol M, Robb LJ, Anhaeusser CR, Gericke B (2003) A review of the geochronological constraints on the evolution of the Kaapvaal Craton, South Africa. Precambr Res 127:181-213. https://doi.org/ 10.1016/S0301-9268(03)00187-6

Quiroz D, Belmar M (2010) Geología del Área Bahía Murta-Cerro, Región de Aisén del General Carlos Ibáñez del Campo. Carta Geológica de Chile, Serie Geología Básica No 125:1-34, Servicio Nacional de Geología y Minería.

Ramírez-Sánchez E, Hervé F, Kelm U, Sassi R (2005) P-T conditions of metapelites from metamorphic complexes in Aysen, Chile. J South Am Earth Sci 19:373-386. https://doi.org/10.1016/j.jsames. 2005.04.007

Ramírez-Sánchez E, Deckart K, Hervé F (2007) Significance of 40Ar39Ar encapsulation ages of metapelites from late Palaeozoic metamorphic complexes of Aysen, Chile. Geol Mag 145:1-8. https:// doi.org/10.1017/S0016756807004220

Ramos VA (2008) Patagonia: a Paleozoic continent adrift? J South Am Earth Sci 26:235-251. https://doi.org/10.1016/j.jsames.2008. 06.002

Ramos VA (2009) Anatomy and global context of the Andes: Main geologic features and the Andean orogenic cycle. In: Backbone of the Americas: Shallow Subduction, Plateau Uplift, and Ridge and Terrane Collision, Kay SM, Ramos VA, Dickinson W (eds). Geological Society of America Memoir 204:31-65.

Ramos VA, Naipauer M (2014) Patagonia: where does it come from? J Iber Geol 40:367-379

Ramos VA, Chemale F, Naipauer M, Pazos PJ (2014) A provenance study of the Paleozoic Ventania System (Argentina): transient complex sources from Western and Eastern Gondwana. Gondwana Res 26:719-740. https://doi.org/10.1016/j.gr.2013.07.008

Rapela CW, Pankhurst RJ, Fanning CM, Grecco LE (2003) Basement evolution of the Sierra de la Ventana Fold Belt: new evidence for Cambrian continental rifting along the southern margin of Gondwana. J Geol Soc 160:613-628. https://doi.org/10.1144/ 0016-764902-112

Riccardi A (1971) Estratigrafía en el oriente de la Bahía de la Lancha, Lago San Martín, Santa Cruz, Argentina. Revista Museo De La Plata 61:245-318

Rojo D (2017) Génesis e implicancias tectónica de los metabasaltos del Complejo Metamorfico Andino Oriental en Peninsula La Carmela y La Florida, Lago O’higgins (48 $\left.30^{\prime}-49^{\circ} 00^{\prime}\right)$. Tesis de pre-grado, Universidad Andres Bello, Chile

Rojo D, Calderón M (2018) Pillow metabasalts at La Carmela peninsula, Lago O’Higgins (48 $\left.50^{\circ} \mathrm{S}\right)$ : review, correlations with other Paleozoic complex of Patagonian and tectonic implications. XVI Congreso geológico chileno, Concepción, 2018.

Rojo D, Calderón M, Hervé F, Díaz J, Quezada P, Suárez RJ, Ghiglione MC, Fuentes F, Theye T, Cataldo J, Sándoval J, Viefhaus T, Cataldo J (2021) Petrology and tectonic evolution of late Paleozoic mafic-ultramafic sequences and the Leones Pluton of the Eastern Andean Metamorphic Complex (46-47 $\left.{ }^{\circ} \mathrm{S}\right)$, southern Chile. J South Am Earth Sci. https://doi.org/10.1016/j.jsames.2021. 103198

Saccani E (2015) A new method of discriminating different types of post-Archean ophiolitic basalts and their tectonic significance using Th-Nb and Ce-Dy-Yb systematics. Geosci Front 6:481501. https://doi.org/10.1016/j.gsf.2014.03.006

Saunders AD, Tarney J (1984) Geochemical characteristics of basaltic volcanism within back-arc basins. In: Marginal Basin Geology, Kokelaar BP, Howells MF (eds). Geol Soc London Spec Publ 16:59-76.

Scheepers R, Armstrong R (2002) New U-Pb SHRIMP zircon ages of the Cape Granite Suite: implications for the magmatic evolution 
of the Saldania Belt. S Afr J Geo 105:241-256. https://doi.org/ $10.2113 / 1050241$

Shervais JW (1982) Ti-V plots and the petrogenesis of modern and ophiolitic lavas. Earth Planet Sci Lett 59:101-118. https://doi.org/ 10.1016/0012-821X(82)90120-0

Suárez RJ, Ghiglione MC, Calderón M, Sue C, Martínod J, Guillaume B, Rojo D (2019a) The metamorphic rocks of the Nunatak Viedma in the Southern Patagonian Andes: Provenance sources and implications for the early Mesozoic Patagonia-Antarctic Peninsula connection. J South Am Earth Sci 90:471-486. https://doi. org/10.1016/j.jsames.2018.12.015

Suárez RJ, González PD, Ghiglione MC (2019b) A review on the tectonic evolution of the Paleozoic-Triassic basins from Patagonia: record of protracted westward migration of the pre-Jurassic subduction zone, southern Chile. J South Am Earth Sci. https://doi. org/10.1016/j.jsames.2019.102256

Suárez R, Ghiglione MC, Sue C, Quezada P, Roy S, Rojo D, Calderón M (2021) Paleozoic-Early Mesozoic structural evolution of the west Gondwana accretionary margin in Southern Patagonia. Argentina J South Am Earth Sci. https://doi.org/10.1016/j.jsames. 2020.103062

Sun SS, McDonough WF (1989) Chemical and isotopic systematics of oceanic basalts; implications for mantle composition and processes. In: Magmatism in the ocean basins, Saunders AD, Norry MJ (eds). Geological Society of London 42:313-345.

Thomson SN, Hervé F (2002) New time constraints for the age of metamorphism at the ancestral Pacific Gondwana margin of southern Chile. Revista Geológica De Chile 29:255-271
Uriz NJ, Cingolani CA, Chemale FJr, Macambira M, Armstrong R (2011) Isotopic studies on detrital zircons of Silurian-Devonian siliciclastic sequences from Argentinean North Patagonia and Sierra de la Ventana regions: comparative provenance. Int J Earth Sci 100:571-589. https://doi.org/10.1007/s00531-010-0597-z

Varela R, Gregori D, González P, Basei M (2015) Caracterización geoquímica del magmatismo de arco devónico y carbonífero-pérmico en el noroeste de patagonia, Argentina. RAGA 72:419-432

Vermeesch P (2004) How many grains are needed for a provenance study? Earth Planet Sci Lett 224:441-451. https://doi.org/10. 1016/j.eps1.2004.05.037

Willner A, Hervé F, Massonne H-J (2000) Mineral chemistry and pressure- temperature evolution of two contrasting high-pressure-lowtemperature belts in the Chonos Archipelago, Southern Chile. J Petrol 41:309-330. https://doi.org/10.1093/petrology/41.3.309

Willner AP, Sepúlveda FA, Hervé F, Massonne H-J, Sudo M (2009) Conditions and timing of pumpellyite-actinolite-facies metamorphism in the Early Mesozoic frontal accretionary prism of the Madre de Dios Archipelago (Latitude 50॰20' S; Southern Chile). J Petrol 50:2127-2155. https://doi.org/10.1093/petrology/egp071

Winchester JA, Floyd PA (1977) Geochemical discrimination of different magma series and their differentiation products using immobile elements. Chem Geol 20:325-343

Xia L, Li X (2019) Basalt geochemistry as a diagnostic indicator of tectonic setting. Gondwana Res 65:43-67. https://doi.org/10.1016/j. gr.2018.08.006 